\author{
MAREK SŁOŃ \\ Instytut Historii Polskiej Akademii Nauk
}

\title{
MIASTA PRYWATNE W SIECI MIEJSKIEJ WIELKOPOLSKI XV-XVI WIEKU
}

Zarys treści: Celem artykułu jest ukazanie roli miast prywatnych na tle sieci miejskiej województw kaliskiego i poznańskiego w XV i XVI w. Dla XV stulecia dokonano podziału ośrodków na cztery kategorie z wykorzystaniem kryteriów ilościowych i jakościowych. Dla schyłku wieku XVI zaproponowano rozwinięcie wyliczeń Jacka Wiesiołowskiego na podstawie szerszej podstawy źródłowej. Zestawienie wyników tych dwóch zabiegów posłużyło do ich wzajemnej weryfikacji oraz wskazania zmian w sieci miejskiej XVI stulecia. Spojrzenie przez pryzmat dokonanej klasyfikacji na tę sieć oraz na dynamikę procesu lokacyjnego zamyka niniejsze rozważania.

The content outline: The aim of the paper is to present the importance of private towns in the urban network of Kaliskie Voivodeship and Poznańskie Voivodeship in the $15^{\text {th }}$ and the $16^{\text {th }}$ century. In the analysis of the situation in the $15^{\text {th }}$ century, the urban centres are divided into four categories on the basis of quantitative and qualitative criteria. The analysis of the situation towards the end of the $16^{\text {th }}$ century is based on the calculations of J. Wiesiołowski, expanded by the application of a wider selection of source materials. The results obtained on the basis of these two methodologies are juxtaposed for their mutual verification and in order to indicate changes in the $16^{\text {th }}$-century urban network. The deliberations are concluded with the analysis of the network and the dynamics of the foundation process through the prism of the classification performed in the paper.

Słowa kluczowe: Wielkopolska, miasta, późne średniowiecze, XVI w.

Keywords: Greater Poland, towns, Late Middle Ages, $16^{\text {th }}$ century

Miasta prywatne stanowiły w XVI w. bezwzględną większość w całej Koronie. Dla zjawiska ich dominacji Wielkopolska ma jednak znaczenie szczególne. Wystapiło ono w tej dzielnicy wcześniej niż w pozostałych 
i, przynajmniej do XVI w. włącznie, z większym nasileniem ${ }^{1}$. Jest to fenomen szczególnie interesujący, wziąwszy pod uwagę sąsiedni Śląsk, gdzie ten typ miasta odgrywał w tym samym czasie rolę drugorzędna. A przecież dla urbanizacji Wielkopolski ślaskie wzorce miały decydujące znaczenie. Tymczasem w literaturze przedmiotu rzecz traktowana jest jako oczywista, po prostu zgodna z krajowymi tendencjami. Warto także zauważyć, że za konstatacją dominacji ilościowej miast prywatnych $\mathrm{w}$ niewielkim stopniu poszła weryfikacja ich ogólnej roli w sieci miejskiej, np. udziału w całym potencjale produkcyjnym czy w obrocie handlowym. Można wciąż spotkać upraszczające stwierdzenia, że prywatne miasta można utożsamić z ośrodkami małymi, choć Andrzej Wyrobisz już w 1974 r. wykazał dla XVI-XVII w., że było inaczej².

Ze względu na liczebność miast prywatnych i ich różnorodność ukazanie roli tych ośrodków wymaga omówienia sieci miejskiej jako całości. $\mathrm{W}$ odniesieniu do Wielkopolski XV w. była ona dwukrotnie przedmiotem systematycznej analizy ${ }^{3}$. Jacek Wiesiołowski w swym klasycznym już artykule z 1980 r. przedstawił jej zasadnicze cechy i zobrazował na mapie ${ }^{4}$. Niestety, odnośna mapa, zapewne wskutek jakiejś usterki technicznej, zawiera obraz zupełnie sprzeczny z towarzyszącym jej tekstem i ze stanem badań, a autor nie zaprezentował swojej kategoryzacji w żaden inny sposób. Sześć lat później Henryk Samsonowicz, korzystając m.in. z tych ustaleń, opublikował listę miast Korony w podziale na cztery kategorie ${ }^{5}$. Zaznaczył przy tym z góry, że należy traktować to zestawienie jako „wstępne” i jedynie propozycję. Obaj badacze przyjęli cały zespół kryteriów porządkujących, a kwalifikacja ośrodków miejskich miała być ich wypadkową. Ze względu na obszerność materiału żaden $\mathrm{z}$ autorów nie udokumentował konkretnych podstaw swojego wyboru w odniesieniu do poszczególnych miast.

${ }^{1}$ A. Wyrobisz, Rola miast prywatnych $w$ Polsce XVI-XVII wieku, PH, t. 65, 1974, s. 19-20; tenże, Miasta prywatne $w$ Polsce XVI-XVII w. jako inwestycje kulturalne, KHKM, t. 26, 1978, s. 47.

2 Tenże, Rola..., s. 30; por. D. Mazek, Ku ozdobie i profitowi. Prawodawstwo miast prywatnych Wielkopolski 1660-1764, Warszawa 2003, s. 9-16.

${ }^{3}$ Ogólne charakterystyki sieci miejskiej bez kategoryzacji miast sa oczywiście liczniejsze; zob. np. A. Gasiorowski, Nasilanie się procesów urbanizacyjnych. Rozwój produkcji przemystowej i handlu, w: Dzieje Wielkopolski, t. 1, red. J. Topolski, Poznań 1969, s. 262-270; Z. Górczak, Najstarsze lokacje miejskie w Wielkopolsce (do 1314 r.), Poznań 2002.

${ }^{4}$ J. Wiesiołowski, Sieć miejska $w$ Wielkopolsce XIII-XVI wieku. Przestrzeń $i$ społeczeństwo, KHKM, t. 28, 1980, nr 3, s. 385-395.

${ }^{5}$ M. Bogucka, H. Samsonowicz, Dzieje miast i mieszczaństwa $w$ Polsce przedrozbiorowej, Wrocław 1986, s. 106-118. 
Istnieją oczywiście liczne opracowania bardziej szczegółowe, przede wszystkim ogólne charakterystyki w pracach syntetycznych, ujęcia tematyczne oraz monografie poszczególnych miast. Moga one być pomocne $\mathrm{w}$ tworzeniu syntezy sieci miejskiej Wielkopolski u schyłku wieków średnich i w początkach epoki nowożytnej. Takie opracowanie jest niewątpliwie potrzebne. Niniejszy tekst nie może jednak w żadnym razie aspirować do takiej roli i musi być ograniczony do wybranych aspektów. Dla XV w. będzie to korekta listy opracowanej przez Henryka Samsonowicza. Następnie dla schyłku wieku XVI zostanie zaproponowane rozwinięcie wyliczeń Jacka Wiesiołowskiego na podstawie szerszej podstawy źródłowej i z głębszym uzasadnieniem dokonanego wyboru metodologicznego. Zestawienie wyników tych dwóch zabiegów posłuży do ich wzajemnej weryfikacji oraz wskazania zmian w sieci miejskiej XVI stulecia. Spojrzenie przez pryzmat dokonanej klasyfikacji na tę sieć oraz na dynamikę procesu lokacyjnego zamknie niniejsze rozważania.

Zanim jednak przejdziemy do analizy historiograficznych konstrukcji należy rozważyć możliwość posłużenia się gotową listą i kryteriami z badanej epoki. Zgodnie z ustawami sejmowymi 1520 r. do miast wielkich został zaliczony Poznań, do drugiego ordynku wskazanych imiennie 11 ośrodków, a dwie najniższe kategorie miało różnić posiadanie lub nie targu lub jarmarku ${ }^{6}$. Ranga Poznania nie budzi wattpliwości bez względu na przyjęte zasady klasyfikacji. W odniesieniu do miast dużych dysponujemy względnie bogatym zasobem wiadomości i wiadomo, jak staramy się wykazać niżej, że ośrodków porównywalnych do tych wymienionych w źródle było co najmniej dwa razy tyle. Natomiast zweryfikowanie liczby targów i jarmarków faktycznie funkcjonujących napotyka na barierę w postaci zbyt ograniczonej podstawy źródłowej. W odniesieniu do niewielkich ośrodków zazwyczaj uchwytne jest jedynie wydanie stosownego przywileju, a w przypadku miast tej rangi nie jest to wystarczające potwierdzenie jego późniejszego istnienia ${ }^{7}$. Sugestywnym przykładem może być przypadek miasteczka Żmij (Żmin, Ziemin, Zimin), które było lokowane przed połową XV w. w pobliżu wsi Modrze. Jeszcze przed końcem stulecia utraciło charakter miejski i zostało wchłonięte przez sąsiednią wieś. Miało jednak nadane prawo

${ }^{6}$ Volumina constitutionum, t. 1, vol. 1: 1493-1526, wyd. S. Grodziski, I. Dwornicka, W. Uruszczak, Warszawa 1996, s. 350-362.

7 Por. np. Babimost, Mosina, Sarnowa i Czaplinek, w: Stownik historyczno-geograficzny ziem polskich $w$ średniowieczu, red. T. Jurek, www.slownik.ihpan.edu.pl (2 IX 2015; dalej: SHG) - pierwsza wzmianka na temat targu lub jarmarku jest jednocześnie ostatnia. 
do targów i jarmarków ${ }^{8}$. Posługiwanie się tym kryterium jest zreszta zawodne także w drugą stronę: brak odpowiedniej wzmianki nie uprawnia do domysłu, że dany ośrodek nie miał praw do targu ani jarmarku? Podsumowujac: ani lista miast drugiego ordynku, ani zasady klasyfikacji podane w konstytucjach sejmowych z 1520 r. nie moga być podstawą dla analizy struktury sieci miejskiej Wielkopolski w końcu XV w.

Lista kryteriów kategoryzacji miast zaproponowana przez Henryka Samsonowicza ma charakter otwarty. Autor bierze pod uwagę listę miast pierwszego i drugiego ordynku z ustawy o pogłównym z 1520 r., spis pieszych wystawianych przez miasta na wojnę trzynastoletnią (1458 r.), podatek koronacyjny 1507 r., dane z lustracji i rejestrów poborowych, zróżnicowanie społeczne i obecność przedmieść, funkcjonowanie gmin żydowskich, specjalizację produkcyjna, pełnione funkcje administracyjne, zasięg kontaktów znajdujący odzwierciedlenie w księgach miejskich i ogólną spuściznę kancelarii miejskiej. Rzeczywiste uwzględnienie tak wielu aspektów mogło jednak dotyczyć jedynie przyporządkowania miast do grupy II (duże) lub III (średnie), a tylko wyjątkowo granicy między trzecim a czwartym ordynkiem. Dla miast małych bardzo rzadko dysponujemy takim zasobem źródeł. Analiza dokonanej kategoryzacji wskazuje, że faktyczna podstawą do wyróżnienia nie tylko miast małych, ale także dużych była liczba zbrojnych ze spisu z 1458 r. Cezurami dla grupy ośrodków średniej wielkości było odpowiednio 10 i 4 piechurów. Za małe zostały uznane te z mniejszą liczbą lub pominięte. Od tych prostych zasad udało się stwierdzić pięć wyjątków. Dwa miasta występujące obok siebie na liście alfabetycznej zostały zamienione miejscami: będące ważnym ośrodkiem Rogoźno trafiło do kategorii IV, a skromny Ryczywół do II. Czwartą kategorię otrzymał Jarocin, który wystawiał 10 zbrojnych w 1458 r., a w XVI w. płacił ponad 27 florenów szosu - jest to prawdopodobnie zwykła pomyłka. Dwa spośród miast nieuwzględnionych w spisie z $1458 \mathrm{r}$. znalazły się w kategorii III: Wałcz prawdopodobnie jako stolica powiatu, Czaplinek zaś z powodów trudnych do odgadnięcia, ale bezzasadnie, ponieważ wszystkie wzmianki źródłowe ukazuja go jako miasto małe ${ }^{10}$. Przyjęcie za podstawę jednej serii danych można by uznać za właściwe, gdyby nie towarzyszyła mu deklaracja zastosowania nieporównanie bardziej złożonych przesłanek.

8 W klasyfikacji H. Samsonowicza zostało podane dwukrotnie, pod nazwami Ziemin i Modrze, i w obu przypadkach błędnie przyporządkowane do woj. kaliskiego.

${ }_{9}$ Jest to możliwe na podstawie Metryki Koronnej, ale jedynie dla ośrodków lokowanych po 1444 r., a te stanowiły jedynie jedna piąta miast Wielkopolski.

${ }^{10}$ Czaplinek, w: SHG. Obok wskazanych tu pomyłek warto jeszcze wskazać 19 przypadków (na 180 uwzględnionych) błędnej przynależności do województwa. 
Jacek Wiesiołowski zaproponował zamkniętą listę mierzalnych kryteriów: liczbę piechurów wystawionych w 1458 r. (odpowiednio 20 i 6), wysokość cyzy (5 i 1 grzywna) ${ }^{11}$, posiadanie odpowiednich instytucji kościelnych (duże - konwent mendykancki, średnie - szpital) oraz organizacja społeczna pospólstwa (duże - udział we władzach, średnie - istnienie cechów). Choć w odróżnieniu od Henryka Samsonowicza formalnie ograniczył się do trzech grup, faktycznie wyłączył z klasyfikacji Poznań jako miasto o innej skali niż pozostałe. W istocie $\mathrm{w}$ obu przypadkach mamy więc do czynienia ze skala czterostopniowa, w której Poznań jest klasa sama w sobie. Mimo to sa to kategoryzacje bardzo rozbieżne. Wiesiołowski zidentyfikował, pomijając Poznań, tylko 8 miast dużych przy 24 u Samsonowicza. Wiadomo, że w województwie kaliskim znalazły się w tym gronie Kalisz, Gniezno, Pyzdry, Środa i Koźmin. W poznańskim na pewno zakwalifikował do tej kategorii Wschowę i Kościan ${ }^{12}$; poza tym przynajmniej trzy kryteria spełniał jeszcze Śrem. Warto zauważyć, jak bardzo ta lista różni się od zestawienia miast drugiego ordynku z konstytucji sejmowej 1520 r.: zawiera nieobecne tam Pyzdry, Środę i zapewne Śrem, a jednocześnie pomija Żnin, Buk, Słupcę, Szamotuły, Grodzisk i Koło. Zwraca też uwagę fakt, że do grupy miast dużych Wiesiołowski zaliczył zaledwie 6\% (pomijając Poznań $5 \%)$ ośrodków. Budzi to wątpliwości, czy zastosowano właściwe kryteria podziału. Najważniejszym i zarazem najbardziej kontrowersyjnym jest obecność konwentu żebraczego. Na ziemiach polskich związek między obecnością takiej placówki a ranga ośrodka miał zupełnie inny charakter niż w Europie Zachodniej, wystarczy porównać udział środowiska miejskiego i książęcego $\mathrm{w}$ procesie fundacyjnym. W Wielkopolsce znamienna jest nieobecność mendykantów w dużych miastach kościelnych, jak Słupca czy Buk, i zarazem obecność w znacznie mniejszych ośrodkach prywatnych, jak Kobylin, Sieraków i Wronki. Konwenty takie moga więc być względnie ważna, ale jednak tylko pomocnicza przesłanka w klasyfikacji. Liczba pieszych wystawionych w 1458 r. stanowi znakomity miernik potencjału miasta. Zbyt wysoka wydaje się jednak użyta przez Wiesiołowskiego granica - 20 zbrojnych. Zapewne było to pochodną kryterium kościelnego. Jeśli jednak spojrzymy na listę miast drugiego ordynku i zestawimy ją z wykazem z 1458 r., to w sposób naturalny wynika z niego cezura 12 - tylu wystawiły Szamotuły

11 J. Wiesiołowski, Sieć miejska..., aneks: Rejestr piechoty wielkopolskiej z 1458 r.; A. Bieniaszewski, J. Latzke, Rejestr poboru cyzy z miast Wielkopolski w latach 1462 -1465 , PH, t. 68,1977 , s. 541-553.

12 J. Wiesiołowski, Sieć miejska..., mapa 4 i 6. 
i Grodzisk, należące do tej grupy, oraz Lwówek i Pleszew, które również z innych względów można zaliczyć do znacznych ośrodków w tym okresie. Większą lub równą liczbę zbrojnych przypisano łącznie 25 miastom województw poznańskiego i kaliskiego. Kolejnym kryterium poznańskiego badacza była wysokość płaconego czopowego. Nie sprecyzował jednak, czego dotyczy podana wartość 5 grzywien. Możemy się jedynie domyślać, że chodziło o wysokość pojedynczej raty, trudno jednak wskazać, której względnie jak liczonej ('średnia? najwyższa?). Ostatnia z podanych przez autora przesłanek, czyli obecność we władzach przedstawicieli pospólstwa jako reprezentantów cechów, dla której nie wskazał żadnych źródeł, opracowań czy choćby uzasadnienia, jest trudna do weryfikacji i w tym miejscu ja pominiemy.

Jako wartości graniczne między grupa średnich i małych miast Wiesiołowski zaproponował sześciu piechurów w 1458 r., co jest wartościa do zaakceptowania, i 1 grzywnę czopowego, do której trudno się odnieść z powodów wyłożonych wyżej. Miasta średnie miały się jego zdaniem wyróżniać posiadaniem szpitala. Nie wiemy, ile placówek tego typu zidentyfikował poznański badacz. Łaczna liczba odnalezionych przez Józefa Nowackiego i wymienionych w Liber beneficiorum Łaskiego wyniosła 46, co należy traktować jako orientacyjna, w tym $9 \mathrm{w}$ miastach uznanych za duże. W średnich pozostałoby ich więc 37 , a liczbę ośrodków średniej wielkości Wiesiołowski ustalił na 57. Ponad jedna trzecia byłaby więc pozbawiona instytucji, która miała decydować o ich statusie. Trzeba oczywiście wziąć pod uwagę możliwość, że jakiś szpital istniał i nie mamy o nim odpowiednich informacji, na pewno jednak nie była to sytuacja tak częsta. Placówki dobroczynne należałoby więc raczej traktować jako pomocnicze kryterium świadczące ogólnie o randze miasta. Wreszcie ostatnie kryterium to obecność cechów rzemieślniczych. Tu wątpliwości w odniesieniu do kompletności naszej wiedzy sa znacznie większe niż w przypadku szpitali. Trudno jednak zaprzeczyć, że potwierdzone, faktyczne funkcjonowanie stowarzyszeń cechowych jest cenną wskazówką za przynajmniej średnim statusem ośrodka. Ze względu na trudność przeprowadzenia pełnej kwerendy przesłanka ta nie zostanie wykorzystana w sposób systematyczny.

Podstawa dla przedstawionej w niniejszym tekście kategoryzacji miast Wielkopolski będa przede wszystkim wymienione przez obu badaczy dane liczbowe: liczba pieszych wystawianych w 1458 r., pobór cyzy w latach 1463-1464, podatek koronacyjny 1507 r., wysokość szosu odnotowana w rejestrach poborowych z drugiej połowy XVI w. Choć te ostatnie dane są późne, moga być efektywnie użyte w tym kontekście, ponieważ opłata ta $\mathrm{w}$ końcu XV w. nabrała charakteru ryczałtowego 
i zazwyczaj pozostawała stabilna. Trzeba jednocześnie zaznaczyć, że w przypadku znacznego rozwoju lub upadku ośrodka miejskiego wysokość szosu bywała jednak zmieniana. Ponadto zostana wzięte pod uwage wskazane przez Wiesiołowskiego typy placówek kościelnych konwenty mendykanckie i szpitale. Za warunek wystarczający i zarazem niekonieczny dla statusu dużego ośrodka przyjmujemy jego obecność na liście miast drugiego ordynku oraz istnienie murów obronnych. Oba kryteria spełniało 9 ośrodków: Poznań, Kościan, Kalisz, Wschowa, Gniezno, Słupca, Koźmin, Żnin i Buk. Na liście z 1520 r. znalazły się trzy miasta nieobwarowane: Koło, Grodzisk i Szamotuły. Jednocześnie zabrakło tam 5 otoczonych murami: Stawiszyna, Międzyrzecza, Konina, Środy i Pyzdr. Wszystkie wystawiały przynajmniej 12 zbrojnych w 1458 r., zapłaciły w latach 1463-1464 przynajmniej 20 florenów cyzy (za wyjątkiem Grodziska, który uiszczał połowę tej sumy) i posiadały szpital. Przyjmijmy te kryteria za wyjściowe dla grupy miast dużych. Odpowiednią liczba pieszych i szpitalem mogło się wykazać jeszcze 8 ośrodków. Śrem wystawił w 1458 r. 20 zbrojnych, zapłacił 20 grzywien podatku koronacyjnego w 1507 r., a cyzy w latach 1463-1464 prawie 38 florenów rocznie, szosu w drugiej połowie XVI w. ponad 38 florenów, miał konwent mendykancki i szpital. Jego przyporządkowanie do miast dużych nie budzi wątpliwości. Na Pobiedziska przypadło 15 pieszych i miały one swój konwent mendykancki. Odpowiednio wysoką cyzę (20 florenów rocznie) płacił również Pleszew, a wysokość jego szosu wynosiła w XVI w. 32 floreny, co także plasuje go wśród ośrodków dużych. Niższa cyzę (13 florenów) i znacznie wyższy szos uiszczał Lwówek. W przypadku Obornik szos był niższy, choć i tak wynosił niemal 30 florenów, i miały one klasztor franciszkański. Królewskie Rogoźno płaciło ponad 40 florenów szosu i nie był to skutek ich szybkiego wzrostu w XVI w. Najwięcej wątpliwości może budzić klasyfikacja Wrześni i Gostynia. Mimo że oba miasta wystawiały po 15 piechurów w 1458 r., wysokość ich cyzy odpowiadała raczej średnim wartościom, nie przekraczając 10 florenów rocznie. Również szos, o wysokości niespełna 20 florenów, nie odróżniał ich od najprężniejszych ośrodków kolejnej grupy. Można jednak przyjąć, że liczba wystawianych zbrojnych jest lepszym wskaźnikiem niż podatek od trunków, w pewnej mierze zależny od specjalizacji gospodarczej konkretnego ośrodka.

Znacznie trudniejsze jest odróżnienie miast średnich od małych. Jeżeli weźmiemy pod uwagę liczne kryteria, jak w odniesieniu do dużych, to dla znacznej części analizowanego materiału nie będzie żadnych danych. W dodatku te, które posiadamy w postaci pojedynczych wzmianek, mają ograniczoną wiarygodność, jak to pokazano 
wyżej w odniesieniu do targów i jarmarków. Podobnie wygląda sprawa z obecnością cechów. Ułomną przesłanka, szczególnie jako argument za wyłączeniem z grupy miast średnich, jest brak szpitala. Dysponujemy natomiast trzema seriami danych, które odnoszą się do większości analizowanych miast: liczba pieszych wystawionych w 1458 r., wysokość cyzy zapłaconej kilka lat później oraz szosu uiszczanego w drugiej połowie XVI w. Ustalenie pełnej liczby miast, i tym samym precyzyjne określenia grupy nieoświetlonej tymi źródłami, napotyka na trudności. Jacek Wiesiołowski podaje liczbę 202 ośrodków, nie załącza jednak ich listy. Henryk Samsonowicz uwzględnia łącznie 180 miast. W niniejszej analizie zostały uwzględnione 174 osady, z czego 160 otrzymało prawa miejskie przed XVI w. W dalszych wyliczeniach punktem odniesienia będzie ta ostatnia liczba. 87 miast, czyli ponad połowa, występuje na wszystkich trzech listach. Informacje o liczbie zbrojnych z 1458 r. dotyczą 135 (84\%) spośród tych ośrodków. Dane na temat cyzy obejmuja natomiast tylko 102 (64\%) miasta. Późniejsze i kompletniejsze są wiadomości na temat szosu, odnoszące się do 130 (81\%) miejscowości z tej listy. Dla pięciu miast nie mamy danych w żadnej z tych trzech serii, dla sześciu brakuje informacji o liczbie pieszych w 1458 r. lub o szosie, czyli te dwa zestawienia obejmują łącznie 96\% analizowanych ośrodków. Grupa miast niewystarczająco naświetlona przez te serie źródłowe jest więc na tyle mała, że każdy z tych przypadków można rozważyć odrębnie. Braki w danych nie rozkładają się zresztą równomiernie na badanym obszarze. Na 25 miast pominiętych w spisie z 1458 r. 11 leży w powiatach nakielskim lub wałeckim. Również w pozostałych dwóch zestawieniach ten rejon jest najsłabiej obecny. Trzeba więc $\mathrm{w}$ tym miejscu zastrzec, że podział na miasta średnie i małe dla północnych rubieży Wielkopolski ma w znacznej mierze walor hipotezy. Z drugiej strony oznacza to, że dla pozostałych powiatów nasze dane sa jeszcze kompletniejsze, niż to zaznaczono wyżej. Na przykład spis piechurów z 1458 r. obejmuje $92 \%$ miast z pozostałych powiatów.

Biorąc pod uwage fakt, że przyjęcie samego kryterium liczby zbrojnych dało $\mathrm{w}$ odniesieniu do miast dużych identyczny wynik z klasyfikacją uwzględniającą inne parametry, można rozpoczać określanie granicy między ośrodkami średnimi i małymi także od hipotezy opartej na tym jednym wykazie. Przyjmijmy za Wiesiołowskim cezurę przynajmniej sześciu zbrojnych dla wyższej kategorii. W przedziale od 6 do 12 wystawionych pieszych mieści się zaledwie 30 miast, czyli niewiele więcej niż było w grupie najwyższej. Należy więc zweryfikować, czy część ośrodków mieszczących się w kolejnym przedziale wartości i nieuwzględnionych w wykazie, których jest łącznie 105, nie powinna zna- 
leźć się wśród ośrodków średniej wielkości. Pięciu piechurów wystawiał tylko Tuliszków, który zarazem płacił prawie 10 florenów cyzy rocznie i tym samym jednoznacznie plasował się wśród miast średnich. Natomiast po czterech pieszych odnotowano przy 23 miastach. Cztery z nich - Chwaliszewo, Ostroróg, Stęszew, Kębłowo (Kiebłów) ${ }^{13}$ - miało swoje szpitale, co jest wystarczająca przesłanką do zaliczeniach ich do wyższej kategorii. Dwa kolejne, Zbąszyń i Kiszkowo, nie dysponowały wprawdzie placówką dobroczynna, lecz płaciły w latach 1463-1464 około 8 florenów cyzy rocznie, a w XVI w. względnie wysoki szos, 6-8 florenów. Nakło było stolica powiatu i płaciło 10 florenów szosu. Ponadto cztery miasta wystawiające jeszcze mniejszą liczbę zbrojnych, 2 lub 3, miały swoje szpitale. Znaczenie trzech spośród nich potwierdzają także inne przesłanki. Kostrzyn w czasie tejże wojny płacił ponad 20 florenów cyzy rocznie, natomiast wysokość szosu uiszczanego w XVI w. przez Chodzież przekraczała 10 florenów i tym samym odpowiadała stawkom miast średnich; niewiele mniej, bo 8 florenów, płacił Kórnik (Kurnik). Natomiast Wilczyno płaciło w latach 1463-1464 poniżej 3 florenów cyzy rocznie, a jego szos w XVI wynosił zaledwie 1 floren, należy je więc zaklasyfikować jako ośrodek mały. Bnin i Żerniki wystawiały tylko po trzech pieszych i nie miały szpitala, ale ten pierwszy płacił szos powyżej 10 florenów (przy cyzie powyżej 3), a te drugie uiszczały wysoka cyzę, ponad 7 florenów rocznie. W grupie 25 ośrodków pominiętych w wykazie z 1458 r. żaden nie zapłacił cyzy wyższej niż 5 florenów rocznie. Natomiast dwa nieodnotowane w tamtym spisie trzeba uznać za miasta średniej wielkości: Tuczno miało szpital, a Wałcz był stolica powiatu i zarazem oba płaciły ponad 10 florenów szosu. Taka lub wyższą stawkę tego podatku uiściły cztery kolejne miasta. Biorąc jednak pod uwagę fakt, że w zbliżonym czasie zapłaciły cyzę bardzo niska lub żadna, należy to raczej przypisać wzrostowi szosu w XVI w. W ten sposób 15 ośrodków awansowało do wyższej rangi, niż by na to wskazywały dane z zestawienia piechurów z 1458 r. Struktura czterech kategorii wyglądałaby więc następująco: jedno miasto wielkie, 24 duże, 45 średnich i 90 małych. Łącznie w 24 przypadkach jest to wynik różny od klasyfikacji Henryka Samsonowicza. Taki podział przyjmujemy $\mathrm{w}$ dalszej analizie.

Natomiast dla wieku XVI dysponujemy tylko zestawieniem Jacka Wiesiołowskiego w przywołanej wyżej publikacji. Jego podstawą była

${ }^{13}$ Jeśli nazwa miasta w XV-XVI w. różniła się od obecnej, przy pierwszej wzmiance o danym mieście jest podawana w nawiasie. Na załączonych mapach pokazano nazewnictwo XVI-wieczne. 
Mapa 1. Miasta Wielkopolski w XV w. według kategorii

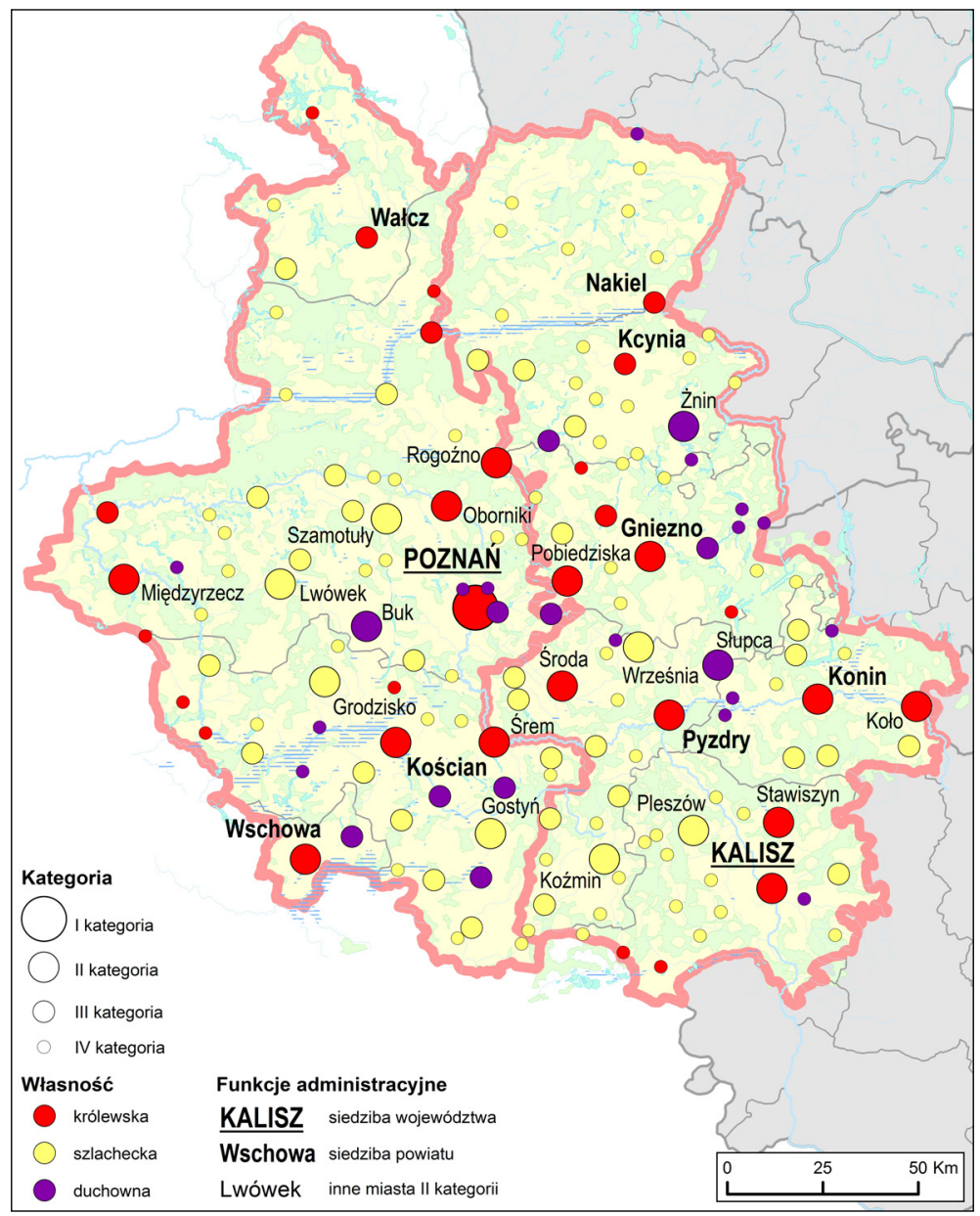

Oprac. kartograficzne: Tomasz Panecki, Marek Słoń na podstawie danych zaprezentowanych w aneksie 1 .

liczba rzemieślników odnotowana w wydanych przez Adolfa Pawińskiego rejestrach poborowych, a pomocniczym miało być czopowe, które jednak w większości analizowanych przez niego województw było rejestrowane osobno i nie zostało objęte edycja. Możemy się jedynie domyślać, że poznański badacz miał na myśli podatek od garnców gorzałczanych, czyli od środków produkcji, a nie jej wielkości, i tylko jednego trunku, który nie odgrywał wtedy pierwszorzędnej roli. Liczba rzemieślników miała natomiast nie obejmować piwowarów i gorzelników. Tu znów mamy do czynienia prawdopodobnie z nieporozumie- 
Mapa 2. Miasta Wielkopolski w XV w. według liczby rzemieślników

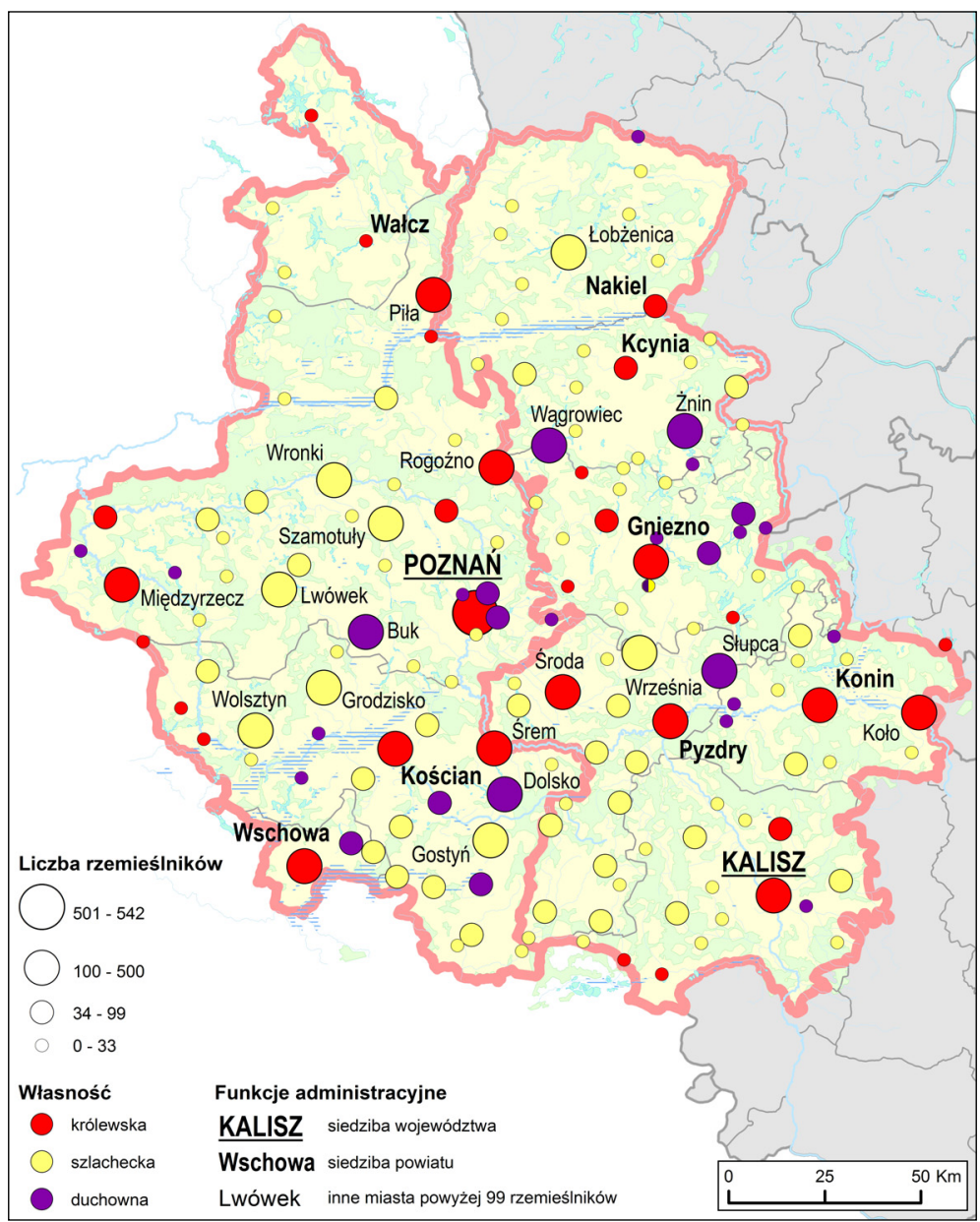

Oprac. kartograficzne: Tomasz Panecki, Marek Słoń na podstawie danych zaprezentowanych w aneksie 1 .

niem. Źródło nie daje podstaw do takich obliczeń, ponieważ te zawody są zazwyczaj ujęte w ogólnej kategorii rzemieślników. Wyróżniona jest natomiast opłata od wyszynku i tę zapewne wykluczał Wiesiołowski ${ }^{14}$. Uwzględnienie kryterium pomocniczego powinno podnieść wiarygodność uzyskanych wyników. Wiele zależy jednak od jego doboru, a w tym

14 J. Wiesiołowski, Sieć miejska..., s. 391; Polska XVI wieku pod względem statystycznym, t. 1-2: Wielkopolska, wyd. A. Pawiński, Warszawa 1883 (Źródła Dziejowe, 12-13). 
przypadku jest on po prostu zły. Wiarygodność rejestrów poborowych była przedmiotem ożywionej dyskusji w literaturze przedmiotu. Wiadomo, że zapis opłaconego podatku z konkretnego poboru często nie był odzwierciedleniem faktycznego potencjału danej osady. W grę wchodziły zarówno zwolnienia z opłat, jak również oszustwa ze strony płatników. Konfrontacja liczby rzemieślników z garncami gorzałczanymi odnotowanymi $\mathrm{w}$ tym samym rejestrze $\mathrm{w}$ żaden sposób nie pomaga przezwyciężyć tych trudności. Mogłaby być użyteczna jedynie pod innym katem: gdyby w pewnych sytuacjach lepiej oddawała rangę miasta niż kryterium główne. Być może poznański badacz znał takie okoliczności i wziął je pod uwagę. W żaden sposób nie podzielił się jednak tą wiedza z czytelnikiem. Nie wiemy nawet tego, czy liczba garnców gorzałczanych ostatecznie wpłynęła choćby w jednym przypadku na przypisana miastu kategorię. Praktycznie musimy założyć, że ukazana na mapie klasyfikacja jest pochodną liczby rzemieślników odnotowanej w edycji Adolfa Pawińskiego.

Związek między ranga miasta a liczbą działających w nim warsztatów jest oczywisty i nie wymaga bliższego uzasadnienia. Trzeba jednak rozważyć ograniczenia tego kryterium. Nawet jeśli produkcja rzemieślnicza byłaby stała i dobrze nam znana, to i tak oddawałaby skalę danego ośrodka tylko wtedy, gdy właśnie ten dział gospodarki w nim dominował. Mogło być jednak inaczej, jeśli podstawą ekonomiczną miasta był np. handel i operacje kredytowe lub rolnictwo. Tę pierwszą możliwość możemy odnieść do Poznania, drugą natomiast do najmniejszych miasteczek. W obu przypadkach nie zmienia to ich przyporządkowania do grup wydzielonych według wielkości.

Największą wadą tej metody, naszym zdaniem ogólnie rzecz biorąc dobrej, jest przypadkowość obrazu zaczerpniętego z jednego spisu. Wzięcie pod uwagę o rząd wielkości większej liczby rejestrów pozwala znacząco ograniczyć możliwy błąd takiego zabiegu. Podstawą poniższych obliczeń będa więc wszystkie pobory z drugiej połowy XVI w. Dla większości powiatów dysponujemy 9 lub 10 spisami, dla kościańskiego 8, dla konińskiego 7. Jedynie w przypadku powiatu wałeckiego podstawa jest dalece niewystarczająca. Sa zachowane tylko 4 rejestry, które $\mathrm{w}$ dodatku często nie zawierają informacji o liczbie rzemieślników. Jednostka ta obejmowała jednak tylko 4 niewielkie miasta, dla dwóch spośród nich sa zreszta pojedyncze wzmianki na temat liczby rzemieślników. Łącznie w grupie 159 miast, których funkcjonowanie w drugiej połowie XVI w. udało się potwierdzić źródłowo, dla pięciu zachowane rejestry poborowe nie zawieraja żadnej informacji o liczbie rzemieślników. Dla kolejnych 11 są to tylko pojedyncze wzmianki, 
od jednej do trzech. Dla 60 mamy dane z 4-6 lat, dla pozostałych $88-$ z co najmniej 7 poborów.

Łącznie jest to ponad 1000 wzmianek źródłowych określających liczbę rzemieślników w konkretnym mieście. Uzyskanie obrazu całości sieci miejskiej wymaga znalezienia narzędzi, które pozwolą zidentyfikować specyficzne cechy tego zbioru danych. Dopiero one powinny być przedmiotem analizy właściwej klasycznemu warsztatowi historycznemu: ocenie wiarygodności, relacji do badanych realiów, korekt, uzupełnień i komentarzy bazujacych na innych źródłach i ogólnej wiedzy o epoce. Alternatywa byłoby poddanie badaniu każdej wzmianki. Abstrahując od teoretycznej możliwości takiego zabiegu przy posiadanej bazie źródłowej, na pewno nie może on być przeprowadzony w tym studium. Natomiast droga pośrednia, czyli korekta danych przed ich opracowaniem matematycznym i następnie ponowna interpretacja uzyskanych wyników byłaby bardzo ryzykowna metodologicznie. $\mathrm{Na}$ obu etapach dokonywalibyśmy podobnego modelowania obrazu na podstawie tych samych uświadomionych i nieuświadomionych założeń. Pełna kontrola takiego piętrowego procesu byłaby bardzo trudna. Tym samym rosłoby ryzyko uzyskania wniosków wypływających bardziej z nastawienia badacza niż z materiału źródłowego. Zebrane dane zostaną więc poddane najpierw analizie czysto matematycznej.

Dla dobrania odpowiedniej metody przekształcenia posiadanego zestawienia $\mathrm{w}$ jednorodny ciag danych trzeba jednak najpierw precyzyjnie określić przedmiot badania. Nie chodzi przecież o liczbę rzemieślników, za których zapłacono w mieście podatek w konkretnym roku. Analizujemy sieć miejska, jej strukturę i rolę składających się na nią grup. Jednocześnie nie jest to badanie jednego momentu, lecz dłuższego okresu, kiedy zmienne były same realia, dodatkowo postrzegane przez pryzmat zapisek niekompletnych i nie w pełni wiarygodnych. Szukamy więc względnie stałej cechy miasta, która przynajmniej po części przybliża liczba odnotowanych rzemieślników. W niniejszym tekście będzie to potencjał miasta i grup miast; pułap ich możliwości udziału $\mathrm{w}$ toczacych się procesach. Patrząc z tej perspektywy, jest oczywiste, że z danych posiadanych dla poszczególnych miast należy wziąc tę najwyższa. Nawet jeśli będzie ona odzwierciedlać okres szczególnej, krótkiej koniunktury, związanej np. z budową kościoła, to zarazem będzie to ślad stanu, który faktycznie zaistniał i tym samym potwierdził taki potencjał miasta. Można uznać za mało prawdopodobne podejrzenie, że płacono podatek za rzemieślników, których wcale w mieście nie było.

Mamy więc 154 obiekty i 154 wartości liczbowe, które opisuja każdy z nich. Szukamy kryteriów podziału tego zbioru na trzy grupy. 
Wiadomo, że ta pierwsza będzie miała najmniej obiektów, ale z najwyższymi wartościami, ta ostatnia odwrotnie, najwięcej obiektów z najniższymi wartościami. Spróbujmy znaleźć takie punkty odcięcia, aby wzajemny stosunek ilościowy kolejnych grup był identyczny lub przynajmniej podobny i to w obie strony: pod względem liczby obiektów i sumy ich wartości. Już sprawdzenie najprostszego przelicznika, czyli podwojenia wartości w kolejnych klasach, daje ciekawy efekt. Sytuacja idealna byłoby, gdyby grupa pierwsza miała 1/7 (14\%) obiektów i 4/7 (57\%) łącznej sumy wartości, ostatnia odwrotnie, tj. 14\% wartości i 57\% obiektów, a dla środkowej oba wskaźniki wynosiłyby 2/7 (29\%). Jeżeli podzielimy listę według liczby obiektów, cezurą będzie miejsce 22. i 66 ., jeśli według wartości - 30. i 70. Gdy wybierzemy punkty pośrednie między nimi, czyli 26. i 68. miejsce na liście (z wartościami granicznymi 99 i 32), najniższa grupa będzie miała 56\% obiektów i $15 \%$ wartości, odbiegając jedynie o jeden punkt procentowy od wstępnych założeń. Odchylenia w podziale między dwie pierwsze grupy są większe, wynosza 3 punkty procentowe, co jest naturalne przy takiej serii danych. Każde przesunięcie w grupie o mniejszej liczbie obiektów i zarazem $\mathrm{z}$ większymi wartościami im przypisanymi musi dać w efekcie większą różnicę w podziale procentowym.

Klasyfikacja dokonywana na podstawie analizy samego ciagu danych nie powinna przyporządkowywać obiektów o identycznych lub zbliżonych wartościach do różnych grup. Najlepiej by było, gdyby wartości graniczne były możliwie odległe od najniższej w górnym i najwyższej $\mathrm{w}$ dolnym przedziale. Idealnego punktu przecięcia można szukać, śledząc po prostu ciag liczb, lecz bardziej efektywną metodą jest obserwacja jego wizualizacji w postaci wykresu.

Oś pozioma oddaje tu kolejne obiekty, odległość między punktami jest więc zawsze jednakowa. Natomiast w osi pionowej, oddającej wartości, rozkład jest nierówny. Odcinki poziome lub prawie poziome to strefy nagromadzenia zbliżonych wartości, które nie powinny być punktem podziału. Natomiast bardziej pionowe odcinki wykresu i widoczne przerwy to właściwe miejsce na wskazanie cezury. Jeśli chcielibyśmy podzielić ten ciag danych na dwie grupy, to w sposób oczywisty narzucałby punkt między 42. a 43. obiektem z wartościami 70 i 62 : pierwsza grupa obejmowałaby $27 \%$ obiektów i $69 \%$ wartości, druga - $73 \%$ obiektów i $31 \%$ wartości ${ }^{15}$. Wróćmy jednak do przyjętego podziału na

${ }^{15}$ Grupę wyższą otwierałaby Krobia, niższa - Łabiszyn. Jak wskazują wszystkie zebrane parametry, ta pierwsza miała w XV w. jeszcze większą przewagę, a późniejsze losy obu miast wskazują na odwrócenie hierarchii najpóźniej w XVIII w. 
Wykres 1. Maksymalna liczba rzemieślników - rozkład wartości (z pominięciem Poznania i Wschowy)

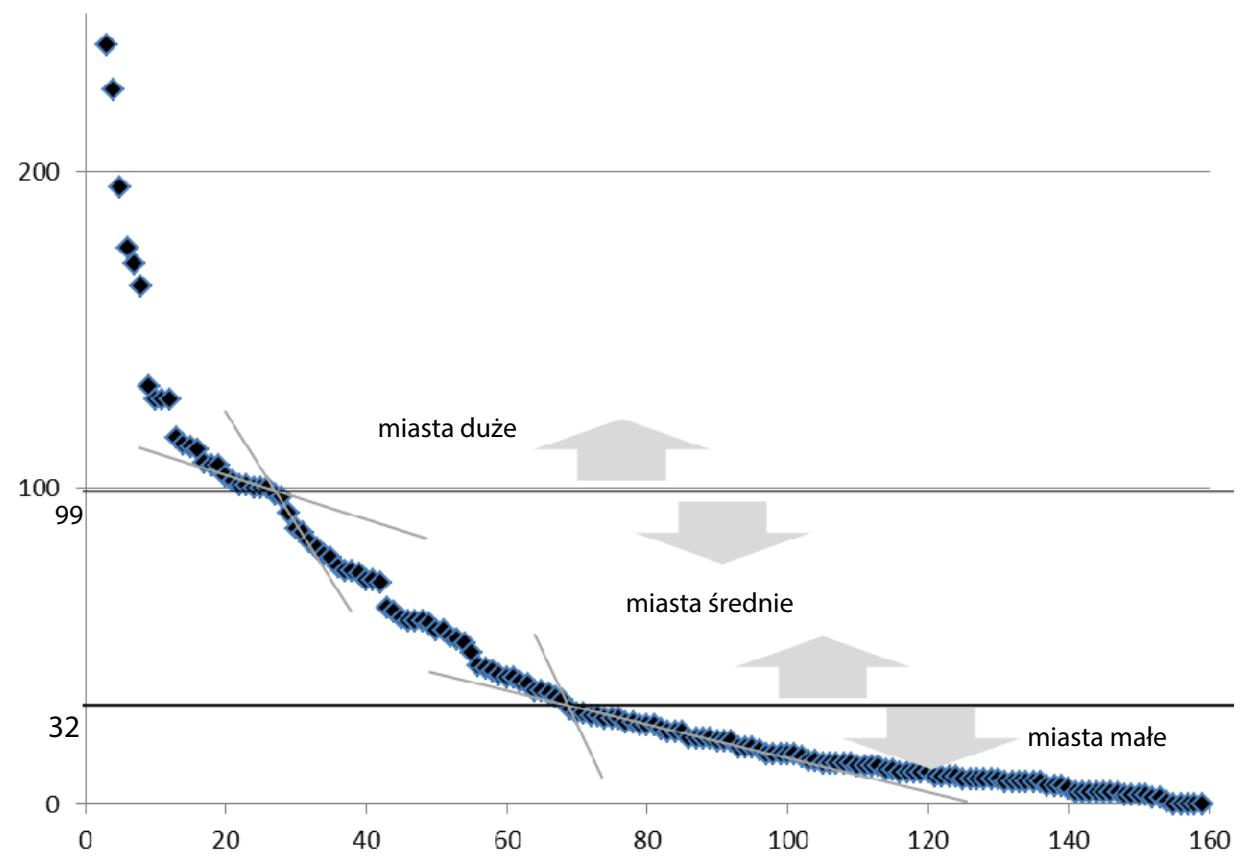

Źródło: oprac. własne na podstawie danych zaprezentowanych w aneksie 1.

trzy grupy. Wytypowane wcześniej linie odpowiadające wartościom 99 i 32 przecinają wyraźne punkty przegięcia wykresu. Wartości 100-102 ma 6 obiektów, a 97-99 tylko dwa, w całym przedziale 87-99 są tylko trzy. Podobnie jest przy kolejnej cezurze: wartości 27-29 ma 7 obiektów, 30-32 tylko 1, 33-35 już trzy i wyżej jest jeszcze gęściej.

Można zatem przyjąć, że dla analizowanego ciagu danych optymalny podział na trzy grupy wygląda następująco: pierwsza obejmuje 26 obiektów z wartościami powyżej 100, druga 42 (wartości 33-98), trzecia zaś liczy 86 jednostek o wartościach 30 i mniejszych. W tym momencie możemy porzucić pole matematyki i powrócić na niwę historii.

Tak skonstruowana struktura wielkości miast może być użyteczna do analizy sieci, jej wybranych grup, obserwowania zjawisk ilościowych. Nie jest to natomiast w żadnym wypadku przyporządkowaniem poszczególnych miast do konkretnych kategorii, może być jedynie ewentualnie punktem wyjścia do takiego zabiegu. Jego przeprowadzenie musi już jednak polegać na wykorzystaniu warsztatu ściśle historycznego. 
Tabela 1. Struktura własnościowa miast Wielkopolski w XV w.

\begin{tabular}{l|c|c|c|c|c|c|c|c}
\hline \multirow{2}{*}{ Kategoria } & \multicolumn{2}{|c|}{ królewskie } & \multicolumn{2}{c|}{ duchowne } & \multicolumn{2}{c|}{ szlacheckie } & \multicolumn{2}{c}{ wszystkie } \\
\cline { 2 - 9 } & liczba & $\%$ & liczba & \% & liczba & $\%$ & liczba & $\%$ \\
\hline I-II & 15 & 60 & 3 & 12 & 7 & 28 & 25 & 16 \\
\hline III & 6 & 13 & 9 & 20 & 30 & 67 & 45 & 29 \\
\hline IV & 10 & 11 & 15 & 17 & 65 & 72 & 90 & 56 \\
\hline Razem & 31 & 19 & 27 & 17 & 102 & 64 & 160 & 100 \\
\hline
\end{tabular}

Źródło: oprac. własne na podstawie danych zaprezentowanych w aneksie 1.

Wśród dużych ośrodków bezwzględnie dominowały królewskie. Rzeczą bardziej symptomatyczną wydaje się jednak właśnie względnie silny udział miast szlacheckich i duchownych w tej kategorii, wynoszacy aż 40\%. Trzeba przy tym pamiętać o nierównościach w obrębie tej grupy. Przewaga Poznania nad wszystkimi pozostałymi była ogromna. Na przykład wysokość zapłaconej cyzy, nawet pomijajac nie do końca jasne dopłaty poza kolejnymi ratami, przekraczała pięciokrotnie stawki drugiego na liście Kościana, a szos czterokrotnie. O status trzeciego miasta Wielkopolski mogły konkurować Wschowa i Kalisz. Dopiero w kolejnej podgrupie obok Gniezna, Pyzdr i Środy pojawia się biskupia Słupca. Wreszcie wśród wyraźnie mniejszych ośrodków widzimy więcej tych kościelnych i prywatnych. Natomiast w pozostałych kategoriach miasta królewskie pełnią rolę wręcz marginalną. Nawet stolice powiatów, jak Kcynia, Nakło i Wałcz, nie wyróżniają się na tle reszty. Poza kilkoma głównymi metropoliami sieć miejską tworzą ośrodki prywatne. Wśród nich wyraźnie dominuja te możnowładcze. Udział Kościoła jest kilkakrotnie mniejszy. Jednocześnie warto zauważyć, że o ile wśród miasteczek na jedno duchowne przypadaja cztery szlacheckie, to wśród średnich już trzy, a dużych - tylko dwa. Potencjał podobny do Słupcy, Buku i Żnina miał zapewne Koźmin, ale pozostałe ośrodki należące do możnych już wyraźnie im ustępowały. Łaczne znaczenie ośrodków kościelnych było większe, niż na to wskazuje sama ich liczba w poszczególnych grupach.

Gdy spojrzymy na tę samą strukturę w końcu XVI w., widać różnice.

Przede wszystkim wyraźnie zmniejszyła się dominacja miast królewskich w pierwszej kategorii. Przesunięcia nastapiły także wewnątrz niej, w tym samym kierunku. Pierwsza, królewska szóstka - Poznań, Wschowa, Kościan, Kalisz, Gniezno, Pyzdry - pozostała bez zmian. Po niej następuje jednak liczna grupa silnych ośrodków prywatnych. Wśród jedenastu kolejnych, dla których odnotowano powyżej 110 rzemieślników, są tylko dwa miasta królewskie - Konin i Śrem. Następna 
Tabela 2. Struktura własnościowa miast Wielkopolski w XVI w.

\begin{tabular}{l|c|c|c|c|c|c|c|c}
\hline \multirow{2}{*}{ Kategoria } & \multicolumn{2}{|c|}{ królewskie } & \multicolumn{2}{c|}{ duchowne } & \multicolumn{2}{c|}{ szlacheckie } & \multicolumn{2}{c}{ wszystkie } \\
\cline { 2 - 9 } & liczba & \% & liczba & \% & liczba & \% & liczba & $\%$ \\
\hline duże & 13 & 50 & 5 & 19 & 8 & 31 & 26 & 27 \\
\hline średnie & 7 & 17 & 8 & 19 & 27 & 64 & 42 & 17 \\
\hline małe & 9 & 10 & 14 & 16 & 63 & 73 & 86 & 56 \\
\hline Razem & 29 & 19 & 27 & 18 & 98 & 64 & 154 & 100 \\
\hline
\end{tabular}

Źródło: oprac. własne na podstawie danych zaprezentowanych w aneksie 1.

jest Piła, również należąca do monarchy, lecz nieobecna w tej kategorii w XV w.; wtedy była miasteczkiem. Koło, Środa i Rogoźno utrzymuja się w grupie ośrodków dużych, lecz na samym końcu listy. Stawiszyn i Oborniki spadły do średnich, a Pobiedziska do małych. Awansu o dwa stopnie do góry dokonały, poza wspomniana przed chwila królewska Piła, dwa miasta szlacheckie: Łobżenica i Wolsztyn. Skromniejszy krok, ze średnich do dużych, poczyniły dwa ośrodki kościelne (Wagrowiec, Dolsk) i jeden możnowładczy (Wronki).

Struktura ilościowa dwóch niższych kategorii pozostała niemal identyczna. Można jedynie wskazać nieznaczny wzrost udziału miast królewskich w tej środkowej. Bliższy ogląd ich składu pokazuje jednak, że nastapiły tu duże i symptomatyczne przesunięcia. Z kategorii czwartej do trzeciej awansowało 11 ośrodków, w tym 8 szlacheckich, 2 duchowne (Mogilno i Śródka) i królewski Żerków. Ruch w druga stronę dotyczył 13 miast, w tym jednego monarszego (Ujście) i jednego kościelnego (Łekno). W grupie ponad 40 miast średnich w XV w. jedynie 27 pozostało w tej samej kategorii sto lat później.

Czy zaobserwowane różnice wskazują na rzeczywiste przemiany, czy też sa pochodną różnych metod sporządzania obu zestawień lub po prostu niewłaściwej klasyfikacji dokonanej dla XVI w.? Przyjrzyjmy się wymienionym wyżej miastom. Regres Łekna nie ulega watpliwości i wiazał się z równoległym wzrostem Wagrowca. Podobnie szybki awans Piły wpłyną na stagnację w Ujściu. Dobra koniunktura w Śródce wydaje się być pochodna wciąż dynamicznego rozwoju Poznania. Względnie wysoką liczbę (42-55) rzemieślników reprezentujących do 10 różnych zawodów potwierdzają w Mogilnie pobory z 8 lat w okresie 1564-1588. Znaczna jest również odnotowana tam liczba garnców gorzałczanych, od 5 do 9. W przypadku Żerkowa jest odnotowanych nawet kilkanaście profesji wzmiankowanych regularnie w latach 1578-1583. Były to wtedy bez wątpienia miasta średniej wielkości. Dla Dolska znakomicie rozwinięte rzemiosło jest potwierdzone tylko w rejestrze z 1563 r., 
ale bardzo wysoki szos, wynoszacy 44 floreny, był uiszczany regularnie przez druga połowę XVI w. W Wolsztynie mamy sytuację odwrotna. Niski szos (8 florenów) świadczy o stosunkowo świeżym awansie, natomiast ponad 100 rzemieślników jest potwierdzonych kilkakrotnie od najwcześniejszego rejestru, z 1563 r., po ostatni, spisany 20 lat później. Łobżenica stała się w XVI w. jednym z najważniejszych ośrodków handlu zbożem $\mathrm{w}$ regionie, a wzrost potencjału miasta potwierdziła udana lokacja nowomiejska. W przypadku Stawiszyna o pewnej stagnacji świadczy nie tyle zaklasyfikowanie go do niższej kategorii 98 rzemieślników plasuje go tuż pod przyjęta cezura, podobną pozycję sugeruje wysokość szosu (32 floreny) i liczba garnców gorzałczanych ile utrata miejsca w pierwszej dziesiątce miast wielkopolskich. Podobnie wygląda sytuacja Obornik: 38 florenów szosu, nawet do 23 garnców gorzałczanych, najwyższa liczba rzemieślników to 81. Spadek Pobiedzisk aż do rzędu miasteczka może budzić wątpliwości, choć liczba dwudziestu kilku rzemieślników jest potwierdzona w kilku latach: w $1564 \mathrm{r}$. było tu aż 12 garnców gorzałczanych, w latach 70. odnotowywano ich wciąż 8 , a wysokość szosu utrzymywała się na poziomie niespełna 20 florenów. Nie ma jednak żadnych wątpliwości, że w stosunku do XV w. nastapił znaczny regres. Podsumowując: trendy zaobserwowane w samym przesunięciu między kategoriami zdają się znajdować potwierdzenie w innych przesłankach. Jest to w pewnym stopniu potwierdzenie poprawności przyjętej metody podziału zbioru danych celem dokonania analiz ilościowych. Nie jest to oczywiście dowód na poprawne przydzielenie kategorii poszczególnym miastom.

Wykorzystajmy zatem wyłonioną matematycznie strukturę do kilku dalszych analiz. Najpierw spójrzmy na rozkład rangi miast w obrębie poszczególnych grup własnościowych.

Tylko wśród miast królewskich także pod względem ilościowym dominowały ośrodki duże. Na drugim miejscu były jednak nie średnie, lecz małe. Wśród duchownych i szczególnie szlacheckich najwięcej było małych. Dobra kościelne charakteryzowały się ponadto większym udziałem dużych miast.

$\mathrm{O}$ znaczeniu grupy miast decydowała jednak nie tyle ich liczba, ile łączny potencjał.

Wyłania się zupełnie inny obraz niż przy analizie samej liczby ośrodków. W dobrach królewskich znaczenie miast średnich i szczególnie małych było wręcz marginalne, przynajmniej pod katem produkcji rzemieślniczej. Również we własności kościelnej najważniejszy był potencjał dużych miast, choć średnie także odgrywały niepośrednią rolę. Jedynie w obrębie posiadania szlachty najważniejsze były te średniej 
Wykres 2. Udział miast różnych kategorii w poszczególnych grupach własnościowych
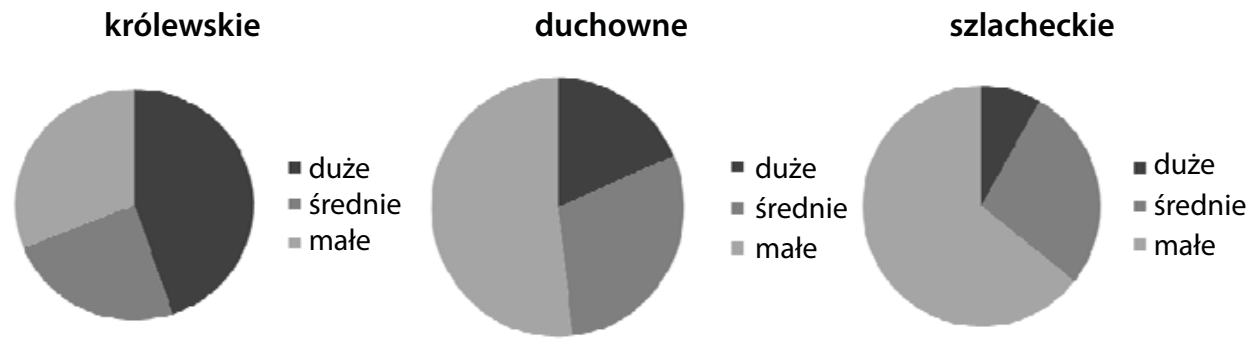

Źródło: oprac. własne na podstawie danych zaprezentowanych w tabeli 2.

Wykres 3. Liczba rzemieślników miast różnej wielkości w poszczególnych grupach własnościowych

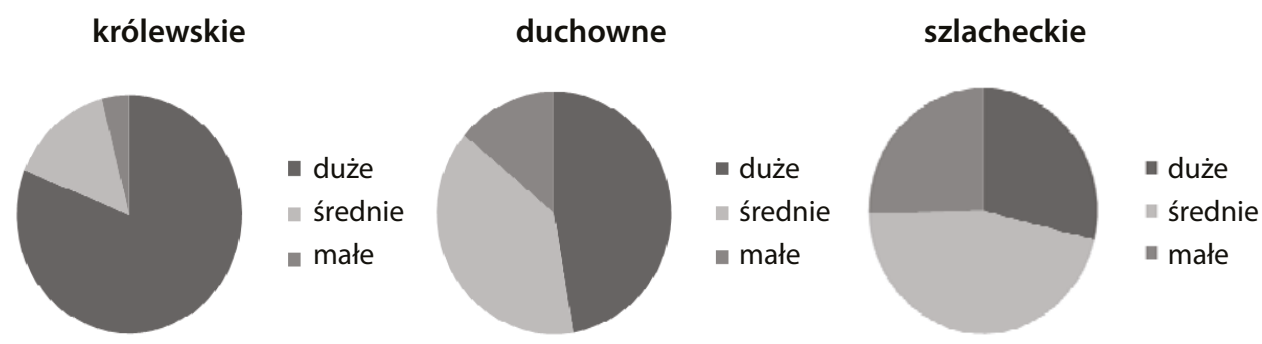

Źródło: oprac. własne na podstawie danych zaprezentowanych w aneksie 1.

wielkości. Również tu najmniejsze znaczenie w skali ogólnej miały miasteczka, natomiast tylko $\mathrm{w}$ dobrach możnowładczych rola ośrodków średniej wielkości rysuje się jako dominująca. Oczywiście przedstawiona tu perspektywa jest nieco sztuczna. Dla poszczególnych właścicieli prywatnych, świeckich i duchownych istotna była „struktura” w obrębie ich włości, czyli często jedno miasteczko.

Łączny potencjał wszystkich miast królewskich był podobny jak tych szlacheckich, a znacząco mniejszą rolę odgrywały duchowne.

Wykres 4. Łączna liczba rzemieślników w miastach różnej własności

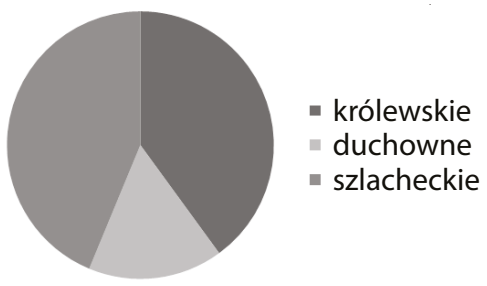

Źródło: oprac. własne na podstawie danych zaprezentowanych w aneksie 1. 
Wydzielenie kategorii według wielkości pozwala także na bliższy ogląd procesu lokacyjnego.

Wykres 5. Dynamika procesu lokacyjnego miast dużych

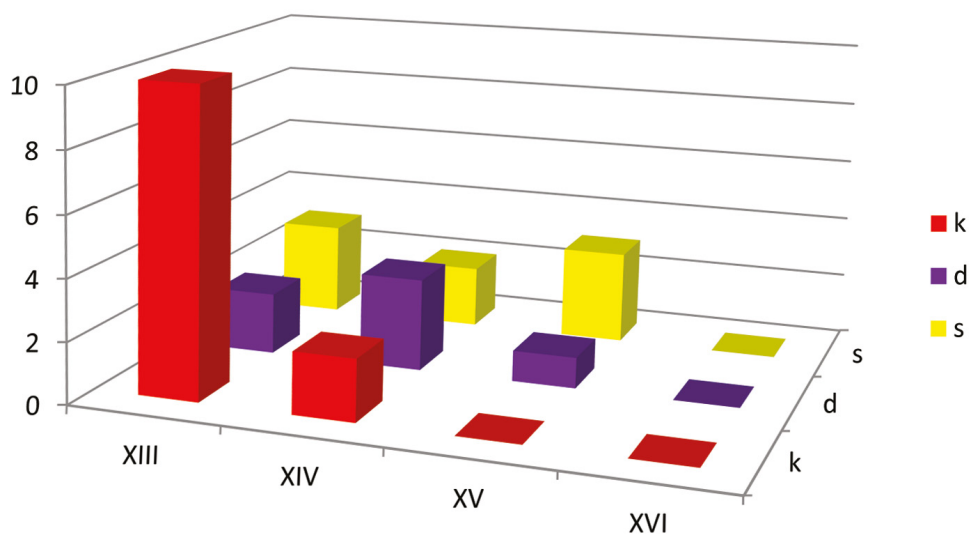

Źródło: oprac. własne na podstawie danych zaprezentowanych w aneksie 1 (miasta: k - królewskie, $\mathrm{d}$ - duchowne, s - szlacheckie).

Żadne z miast powstałych w XVI w. nie stało się przed końcem stulecia dużym ośrodkiem. Takiego awansu nie doświadczyło także żadne miasto królewskie lokowane w XV w., udało się to natomiast kilku szlacheckim. Wśród lokacji XIV-wiecznych żadna grupa własnościowa się nie wyróżnia. Ogólnie rzecz biorąc, w całej tej kategorii dominuja wyraźnie miasta królewskie założone w XIII w.

Wykres 6. Dynamika procesu lokacyjnego miast średnich

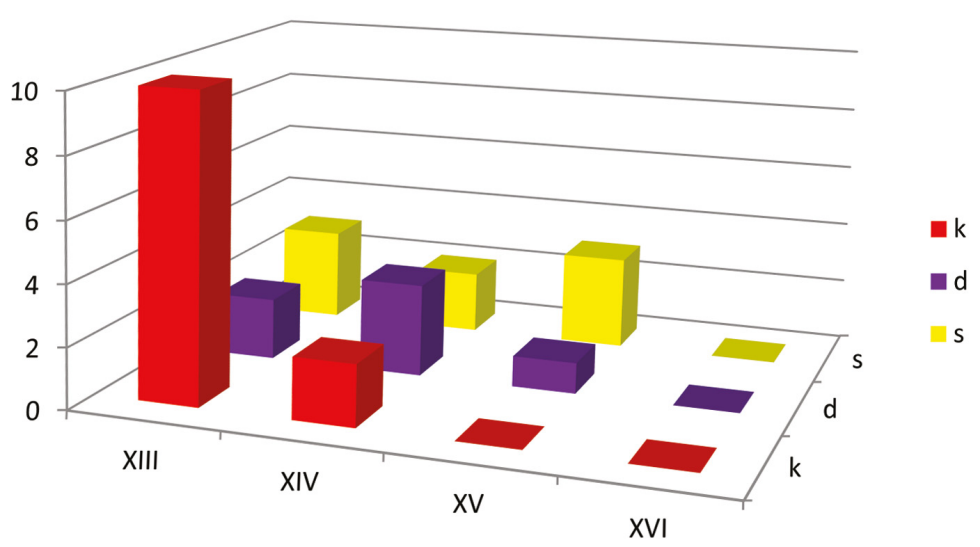

Źródło: oprac. własne na podstawie danych zaprezentowanych w aneksie 1 (miasta: k - królewskie, d - duchowne, s - szlacheckie). 
Również do grona miast średnich zdołała awansować zaledwie jedna lokacja XVI-wieczna - Leszno. Udało się to natomiast kilku ośrodkom możnowładczym powstałym w XV w. Najliczniejszą grupę stanowia miasta tego typu własności lokowane w XIV w.

Wykres 7. Dynamika procesu lokacyjnego miast małych

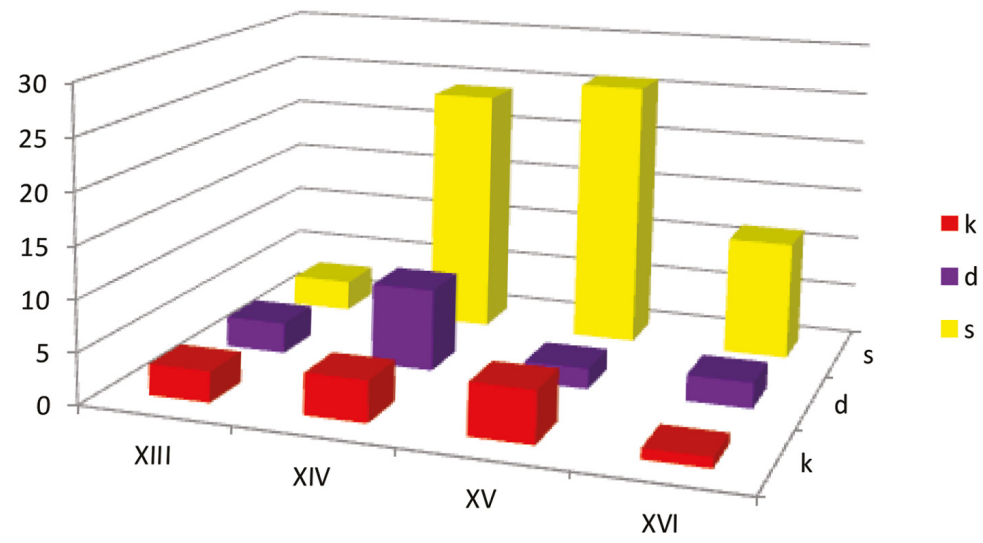

Źródło: oprac. własne na podstawie danych zaprezentowanych w aneksie 1 (miasta: k - królewskie, $\mathrm{d}$ - duchowne, s- szlacheckie).

Rodowód szlacheckich miasteczek mógł sięgać nawet XIII stulecia, ale większość z nich powstała w XIV-XV w. Również stosunkowo liczne były w tej kategorii kościelne lokacje z XIV w., choć znacznie ustępowały one możnowładczym. Rzadko się zdarzało, by miasto założone w XIII w. po 300 latach wciąż było małe, a przypadki takie dotyczyły w równej mierze wszystkich trzech grup własnościowych.

W całym procesie lokacyjnym można wskazać kilka silniejszych nurtów. Pierwszy to inicjatywy monarsze z XIII w., które stały się miastami dużymi. Drugi, największy, to te możnowładcze z XIV w., które zasiliły zarówno szeregi średnich, jak małych miast. Trzeci i ostatni to XV-wieczne założenia szlacheckie, które po stu latach nadal były miasteczkami. Tak ukształtował się zrąb sieci lokacyjnej Wielkopolski.

Udział poszczególnych grup własnościowych w procesie lokacyjnym w kolejnych stuleciach warto także zobrazować na mapie.

Założenia XIII-wieczne koncentrowały się w środkowej i zachodniej części Wielkopolski. Natomiast loakcje możnowładcze z tego okresu sytuuja się na pograniczu tej strefy i są zgrupowane w kilku miejscach. Nowe Miasto, Jarocin, Pleszew i Gostyń na południu, Szamotuły i Wronki na północnym zachodzie, Żerniki i Rynarzewo na północnym wschodzie. Biorąc pod uwagę także zbliżony czas powstania niektórych 
Mapa 3. Lokacje w XIII-XVI w. według własności

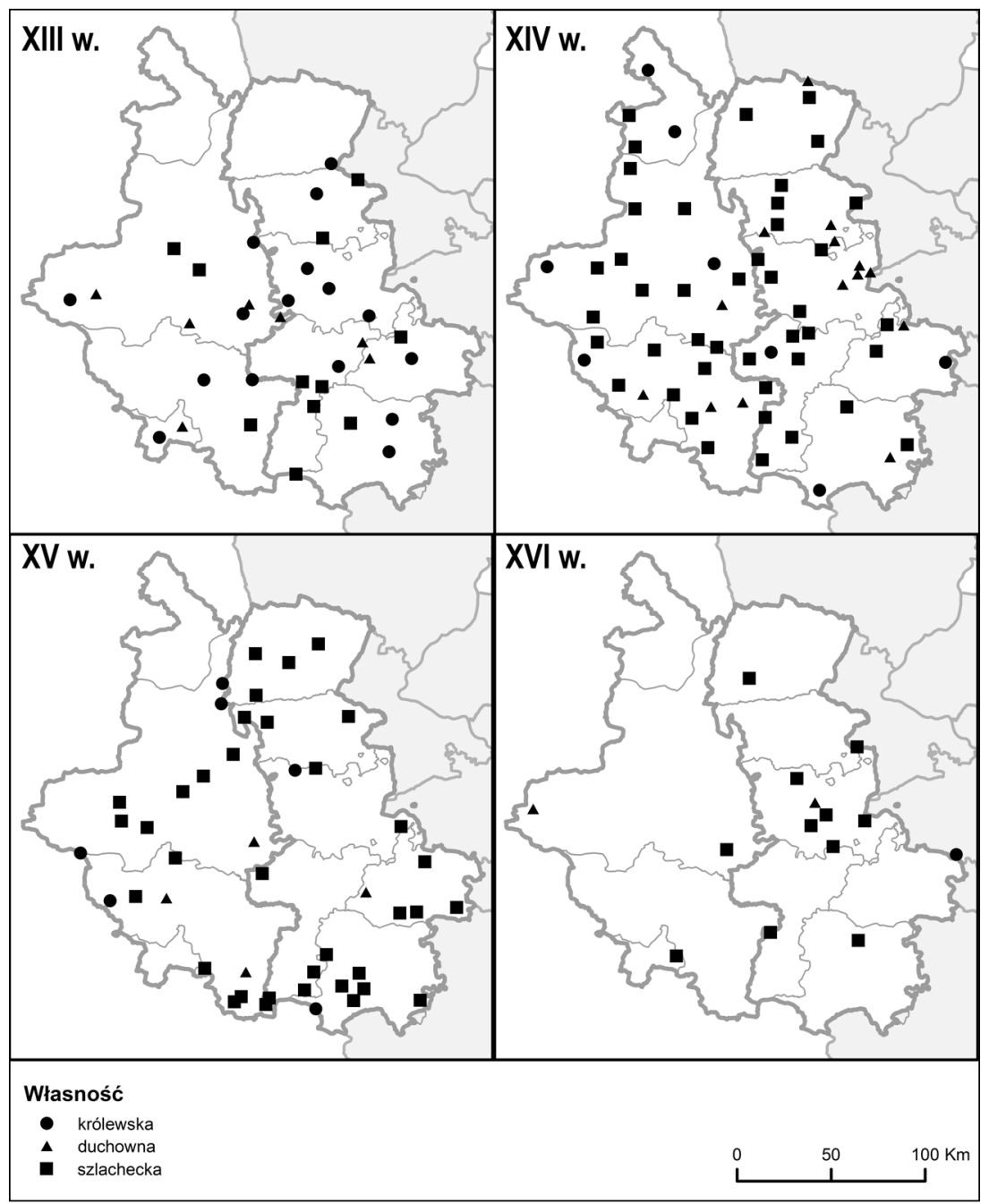

Oprac. kartograficzne: Tomasz Panecki, Marek Słoń na podstawie danych zaprezentowanych w aneksie 1 .

spośród nich, np. Rynarzewo i Żerniki (1298-1299), Pleszew i Nowe Miasto (1283), można się tu dopatrywać lokalnego naśladownictwa. W następnym stuleciu fala lokacji szlaceckich objęła względnie równomiernie cała dzielnicę, tworzać tym samym szkielet jej sieci miejskiej.

W XV w. miasta zakładano niemal wyłącznie na obrzeżach Wielkopolski, a dotyczy to szczególnie ośrodków szlacheckich. Jedynym ośrodkiem powstałym w centralnej części dzielnicy był Kórnik - miasto 
założone niespełna $2 \mathrm{~km}$ od Bnina. Nowe założenie nie uzupełniało więc tu sieci miejskiej, lecz ja zaburzało. Nasuwa to wniosek, że była ona już w tym czasie, poza terenami peryferyjnymi, w zasadzie kompletna. Taki układ przestrzenny późnej fali lokacyjnej byłby jednak zrozumiały, gdyby Wielkopolska stanowiła odrębne państwo z równomiernymi i zarazem niezbyt bliskimi kontaktami z sasiadami. Tak przecież nie było. Trzeba zwrócić uwagę na tereny, gdzie w XV w. zakładano miasta. Na północy był to pas dotąd słabo zaludniony, a w XV w. poddany silnej akcji kolonizacyjnej. Lokacje miejskie były jej częścia. Przyczyna tak późnego zasiedlania powiatu wałeckiego i nakielskiego oraz części poznańskiego było z jednej strony ich graniczne położenie, z drugiej zaś trudne warunki naturalne i względnie niska jakość gleb. Podobne uwarunkowania dotyczyły pogranicza wielkopolsko-kujawskiego. Tu oczywiście w XV w. granicy już nie było, lecz trwały ślady dawnych podziałów dzielnicowych. W przypadku lokacji w południowej części powiatów konińskiego, kaliskiego i pyzdrskiego istotniejszy był aspekt naturalny, czyli przede wszystkim jakość gruntów. Grupa miast powstałych w południowej części powiatu kościańskiego nie zawdzięczała korzystnej koniunktury karczunkowi i zakładaniu nowych wsi, lecz sassiedztwu szybko rozwijającego się Ślasska. Wreszcie kilka nowych założeń na zachodnich rubieżach Wielkopolski można wiązać za wszystkimi wskazanymi wyżej czynnikami: trudniejszymi warunkami naturalnymi, zagęszczaniem sieci osadniczej, stymulujęcemu sąsiedztwu obszarów po drugiej stronie granicy. Podsumowując, ówczesna i dawniejsza granica dzielnicy była tylko jednym z czynników determinujacych zasięg lokacji. Nie zmienia to faktu, że taka dynamika przestrzenna powstawania miast jest świadectwem silnej odrębności Wielkopolski po przeszło stu latach funkcjonowania w obrębie Królestwa Polskiego. Natomiast rozłożenie lokacji XVI-wiecznych nie wykazuje żadnych cech specyficznych. Były one nieliczne, rozrzucone w sposób chaotyczny i miały ograniczone perspektywy rozwoju.

Wnioski płynace z przedstawionych tu rozważań układają się na dwóch płaszczyznach. Pierwsza to metodologia. Dla średniowiecza podstawą była klasyczna analiza wieloaspektowa, łącząca elementy ilościowe z jakościowymi. Dla epoki nowożytnej natomiast punktem wyjścia stała się praca nad danymi o charakterze statystycznym. Uzyskane w ten sposób klasyfikacje miast według ich rangi w XV i XVI w. okazały się porównywalne, a ich zestawienie pozwoliło na zdynamizowanie obrazu badanej sieci miejskiej.

$\mathrm{Na}$ drugiej płaszczyźnie plasują się konkluzje rzeczowe, odnoszące się przede wszystkim do miast prywatnych i ich roli na tle pozostałych. 
Obecna już w literaturze teza na temat istotnej roli tej grupy znalazła nie tylko potwierdzenie, ale również rozwinięcie. Wśród ośrodków szlacheckich największe znacznie miały te średniej wielkości, a nie małe miasteczka. W ogólnym potencjale produkcyjnym miasta prywatne dorównywały królewskim, a wraz z kościelnymi zdecydowanie nad nimi przeważały. Już w XIV w. miejscowe możnowładztwo przejęło pierwsze skrzypce $\mathrm{w}$ procesie lokacyjnym i utrzymało tę pozycję $\mathrm{w}$ następnym stuleciu. Sieć miejska była już jednak wtedy w centralnej części dzielnicy względnie nasycona i nowe ośrodki powstawały głównie na jej peryferiach. Ukazuje to ciekawe zjawisko utrzymywania się odrębności Wielkopolski jeszcze długo po politycznym zjednoczeniu z resztą Korony.

Aneks 1. Dane statystyczne do dziejów sieci miejskiej Wielkopolski w XV-XVI w. ${ }^{16}$

\begin{tabular}{|c|c|c|c|c|c|c|c|c|c|c|c|c|c|}
\hline 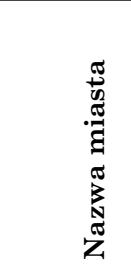 & 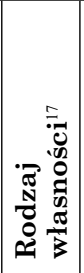 & $\frac{\infty}{3}$ & 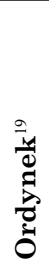 & 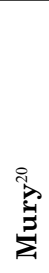 & 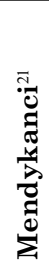 & 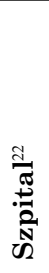 & 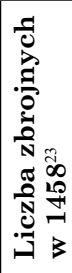 & 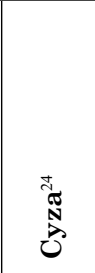 & 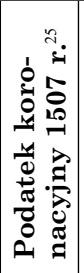 & 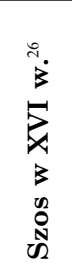 & 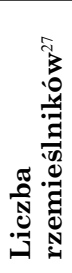 & 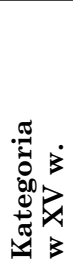 & 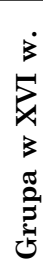 \\
\hline 1 & 2 & 3 & 4 & 5 & 6 & 7 & 8 & 9 & 10 & 11 & 12 & 13 & 14 \\
\hline Poznań & $\mathrm{k}$ & XIII & I & + & + & + & 60 & 1515,6 & 375 & 1400 & 542 & 1 & $\mathrm{~L}$ \\
\hline Wschowa & $\mathrm{k}$ & XIII & II & + & + & + & 20 & 153,4 & 62,5 & 320 & 372 & 2 & $\mathrm{~L}$ \\
\hline
\end{tabular}

${ }^{16}$ Dane te w formie połaczonej z mapa GIS (plik w formacie .mdb) zostaną udostępnione do pobrania na witrynie Atlasfontium.pl.

${ }_{17}$ Atlas historyczny Polski. Rejestry poborowe województwa kaliskiego w XVI w., red. M. Słoń, „Atlas Źródeł i Materiałów do Dziejów Dawnej Polski” 2, 2015, Atlasfontium.pl (31 VIII 2015); Atlas historyczny Polski. Rejestry poborowe województwa poznańskiego $w$ XVI w., red. M. Słoń, „Atlas Źródeł i Materiałów do Dziejów Dawnej Polski” 3, 2015, Atlasfontium.pl (31 VIII 2015); jedną z gmin gnieźnieńskich, Jędrzejewo, oznaczono tu jako szlachecka, mimo istnienia w niej jurydyki duchownej Cierpięgi, ponieważ w rejestrach odnotowano rzemieślników tylko w szlacheckiej części miasta. Oznaczenia typu własności w tabeli: $\mathrm{d}$-duchowna, k. - kościelna, s - szlachecka.

${ }_{18}$ M. Bogucka, H. Samsonowicz, dz. cyt., s. 86; SHG; wiek lokacji podano tylko dla ośrodków, których charakter miejski jest potwierdzony źródłowo w XVI w.

19 Volumina constitutionum..., t. 1, vol. 1, s. 350-362.

${ }^{20}$ J. Widawski, Miejskie mury obronne $w$ Państwie Polskim do poczatku XV w., Warszawa 1973, s. 24, passim.

${ }^{21}$ J. Wiesiołowski, Dominikanie $w$ miastach wielkopolskich $w$ okresie średniowiecza, w: Studia nad historiq dominikanów w Polsce 1222-1972, t. 1, red. J. Kłoczowski, Warszawa 1975, s. 199-215; J. Kłoczowski, Klöster und Orden im mittelalterlichen Polen, Osnabrück 2013, s. 236-303, gdzie zostali pominięci augustianie eremici w Sierakowie; Sieraków, w: SHG. 


\begin{tabular}{|c|c|c|c|c|c|c|c|c|c|c|c|c|c|}
\hline 1 & 2 & 3 & 4 & 5 & 6 & 7 & 8 & 9 & 10 & 11 & 12 & 13 & 14 \\
\hline Kalisz & $\mathrm{k}$ & XIII & II & + & + & + & 30 & 157 & 40 & 231 & 240 & 2 & $\mathrm{~L}$ \\
\hline Kościan & $\mathrm{k}$ & XIII & II & + & + & + & 40 & 310 & 188 & 352 & 226 & 2 & $\mathrm{~L}$ \\
\hline Gniezno & $\mathrm{k}$ & XIII & II & + & + & + & 20 & 202,2 & 31,3 & 54 & 195 & 2 & $\mathrm{~L}$ \\
\hline Pyzdry & $\mathrm{k}$ & XIII & & + & + & + & 30 & 68,8 & 10 & 64 & 176 & 2 & $\mathrm{~L}$ \\
\hline Gostyń & $\mathrm{s}$ & XIII & & & & + & 15 & 8,9 & & 19 & 171 & 2 & $\mathrm{~L}$ \\
\hline Łobżenica & $\mathrm{s}$ & $\mathrm{XV}$ & & & & & 1 & & & 38 & 164 & 4 & $\mathrm{~L}$ \\
\hline Żnin & d & XIV & II & + & + & & 15 & 26,4 & & 47 & 132 & 2 & $\mathrm{~L}$ \\
\hline Słupca & $\mathrm{d}$ & XIII & II & + & & + & 20 & 84,3 & & 96 & 128 & 2 & $\mathrm{~L}$ \\
\hline Konin & $\mathrm{k}$ & XIII & & + & & + & 15 & 54,5 & & 32 & 128 & 2 & $\mathrm{~L}$ \\
\hline Wagrowiec & $\mathrm{d}$ & XIV & & & & & 6 & 14,6 & & 45 & 125 & 3 & $\mathrm{~L}$ \\
\hline Śrem & $\mathrm{k}$ & XIII & & & + & + & 20 & 37,9 & 20 & 38 & 123 & 2 & $\mathrm{~L}$ \\
\hline Wolsztyn & $\mathrm{s}$ & $\mathrm{XV}$ & & & & & 4 & 1,5 & & 8 & 116 & 4 & $\mathrm{~L}$ \\
\hline Lwówek & $\mathrm{s}$ & $\mathrm{XV}$ & & & & + & 12 & 12,9 & & 58 & 114 & 2 & $\mathrm{~L}$ \\
\hline Grodzisko & $\mathrm{s}$ & XIV & II & & + & + & 12 & 11,6 & & 23 & 113 & 2 & $\mathrm{~L}$ \\
\hline Dolsk & $\mathrm{d}$ & XIV & & & & + & 10 & 8,8 & & 45 & 112 & 3 & $\mathrm{~L}$ \\
\hline Piła & $\mathrm{k}$ & $\mathrm{XV}$ & & & & & & & & 7 & 108 & 4 & $\mathrm{~L}$ \\
\hline Międzyrzecz & $\mathrm{k}$ & XIII & & + & & + & 15 & 25,8 & & 26 & 107 & 2 & $\mathrm{~L}$ \\
\hline Buk & $\mathrm{d}$ & XIII & II & + & & + & 15 & 24,8 & & 52 & 104 & 2 & $\mathrm{~L}$ \\
\hline Września & $\mathrm{s}$ & XIV & & & & + & 15 & 9,8 & & 18 & 102 & 2 & $\mathrm{~L}$ \\
\hline Środa & $\mathrm{k}$ & XIV & & + & + & + & 20 & 40,5 & & 64 & 101 & 2 & $\mathrm{~L}$ \\
\hline Koło & $\mathrm{k}$ & XIV & II & & + & + & 15 & 139,2 & 20 & 64 & 101 & 2 & $\mathrm{~L}$ \\
\hline Rogoźno & $\mathrm{k}$ & XIII & & & & + & 15 & 13,3 & & 41 & 100 & 2 & $\mathrm{~L}$ \\
\hline Szamotuły & $\mathrm{s}$ & XIII & II & & & + & 12 & 27,7 & & 32 & 100 & 2 & $\mathrm{~L}$ \\
\hline Wronki & $\mathrm{s}$ & XIII & & & + & & 10 & & & 13 & 100 & 3 & $\mathrm{~L}$ \\
\hline Stawiszyn & $\mathrm{k}$ & XIII & & + & & & 15 & 39,3 & 20 & 32 & 98 & 2 & $\mathrm{M}$ \\
\hline
\end{tabular}

${ }^{22}$ J. Łaski, Liber beneficiorum archidyecezyi gnieźnieńskiej, t. 1-2, wyd. J. Łukowski, J. Korytkowski, Gniezno 1880-1881; J. Nowacki, Dzieje archidiecezji poznańskiej, t. 2: Archidiecezja poznańska $w$ granicach historycznych $i$ jej ustrój, Poznań 1964, s. 650-665; SHG.

${ }^{23}$ J. Wiesiołowski, Sieć miejska..., aneks.

${ }^{24}$ A. Bieniaszewski, J. Latzke, dz. cyt.; podana w tabeli wartość to średnia opłata roczna w latach 1463-1464, we florenach.

${ }^{25}$ H. Rutkowski, Podatek „koronacja” $w$ Polsce na poczatku XVI wieku, w: tenże, Fundamenta historiae. Pisma wybrane, oprac. M. Zbieranowski, M. Słoń, Warszawa 2014, s. 57 n. (dane podane w grzywnach).

${ }^{26}$ Atlas historyczny Polski. Rejestry poborowe województwa kaliskiego...; Atlas historyczny Polski. Rejestry poborowe województwa poznańskiego... (dane podane we florenach).

${ }^{27}$ Atlas historyczny Polski. Rejestry poborowe województwa kaliskiego; Atlas historyczny Polski. Rejestry poborowe województwa poznańskiego... 


\begin{tabular}{|c|c|c|c|c|c|c|c|c|c|c|c|c|c|}
\hline 1 & 2 & 3 & 4 & 5 & 6 & 7 & 8 & 9 & 10 & 11 & 12 & 13 & 14 \\
\hline Jarocin & $\mathrm{s}$ & XIII & & & & + & 10 & 11,2 & & 27 & 97 & 3 & $\mathrm{M}$ \\
\hline Kcynia & $\mathrm{k}$ & XIII & & & & & 6 & 4,8 & & 6 & 92 & 3 & M \\
\hline Chwaliszewo & d & $\mathrm{XV}$ & & & & + & 4 & & & 10 & 87 & 3 & $\mathrm{M}$ \\
\hline Pleszew & $\mathrm{s}$ & XIII & & & & + & 12 & 19,9 & & 32 & 86 & 2 & M \\
\hline Święciechowa & $d$ & XIII & & & & & 10 & 8,4 & & 10 & 83 & 3 & M \\
\hline Oborniki & $\mathrm{k}$ & XIV & & & + & + & 15 & 13,4 & & 29 & 81 & 2 & $\mathrm{M}$ \\
\hline Koźmin & $\mathrm{s}$ & XIV & II & + & + & + & 20 & 31,4 & & 34 & 79 & 2 & M \\
\hline Górka & $\mathrm{s}$ & $\mathrm{XV}$ & & & & & 8 & 5,2 & & 13 & 78 & 3 & $\mathrm{M}$ \\
\hline Zbąszyń & $\mathrm{s}$ & XIV & & & & & 4 & 7,6 & & 8 & 75 & 3 & M \\
\hline Osieczna & $\mathrm{s}$ & XIV & & & & + & 10 & 8,1 & & 19 & 74 & 3 & M \\
\hline Śródka & d & XIII & & & & & 3 & & & 13 & 74 & 4 & M \\
\hline Krotoszyn & $\mathrm{s}$ & $\mathrm{XV}$ & & & & & 2 & 1,7 & & 32 & 73 & 4 & $\mathrm{M}$ \\
\hline Krzywiń & d & XIV & & & & & 10 & 19,2 & & 26 & 71 & 3 & M \\
\hline Poniec & $\mathrm{s}$ & XIV & & & & + & 8 & 12,5 & & 11 & 71 & 3 & $\mathrm{M}$ \\
\hline Krobia & d & $\mathrm{XV}$ & & & & + & 10 & 7,4 & & 16 & 70 & 3 & $\mathrm{M}$ \\
\hline Łabiszyn & $\mathrm{s}$ & XIV & & & & & 4 & & & 6 & 62 & 4 & $\mathrm{M}$ \\
\hline Kleczew & $\mathrm{s}$ & XIV & & & & & 10 & & & 19 & 61 & 3 & $\mathrm{M}$ \\
\hline Leszno & $\mathrm{s}$ & XVI & & & & & & & & 11 & 59 & 4 & M \\
\hline Kłecko & $\mathrm{k}$ & XIII & & & & + & 10 & 26,7 & & 22 & 58 & 3 & M \\
\hline Koźminek & $\mathrm{s}$ & XIV & & & & & 6 & 10,4 & & 8 & 58 & 3 & $\mathrm{M}$ \\
\hline Rydzyna & $\mathrm{s}$ & $\mathrm{XV}$ & & & & & 4 & 3,7 & & 2 & 58 & 4 & $\mathrm{M}$ \\
\hline Żerków & $\mathrm{k}$ & XIII & & & & & 4 & & & 10 & 57 & 4 & M \\
\hline Kobylin & $\mathrm{s}$ & XIV & & & + & + & 10 & 8,1 & & 19 & 55 & 3 & $\mathrm{M}$ \\
\hline Mogilno & $\mathrm{d}$ & XIV & & & & & 2 & 2,8 & & 6 & 55 & 4 & $\mathrm{M}$ \\
\hline Miłosław & $\mathrm{s}$ & XIV & & & & & 4 & 2,7 & & 19 & 53 & 4 & M \\
\hline Nowe Miasto & $\mathrm{s}$ & XIII & & & & + & 10 & 12,2 & & 17 & 52 & 3 & $\mathrm{M}$ \\
\hline Trzemeszno & d & XIV & & & & & 8 & 6,8 & & 10 & 51 & 3 & $\mathrm{M}$ \\
\hline Czarnków & $\mathrm{s}$ & XIV & & & & + & 6 & & & 6 & 48 & 3 & $\mathrm{M}$ \\
\hline Nakło & $\mathrm{k}$ & XIII & & & & & 4 & & & 10 & 44 & 3 & $\mathrm{M}$ \\
\hline Sieraków & $\mathrm{s}$ & XIV & & & + & + & 6 & 12 & & 22 & 43 & 3 & $\mathrm{M}$ \\
\hline Rychwał & $\mathrm{s}$ & $\mathrm{XV}$ & & & & & 6 & 3,1 & & 2 & 42 & 3 & $\mathrm{M}$ \\
\hline Czempiń & $\mathrm{s}$ & XIV & & & & & 3 & & & 4 & 41 & 4 & $\mathrm{M}$ \\
\hline Borek & $\mathrm{s}$ & XIV & & & & & 8 & 2,5 & & 11 & 40 & 3 & $\mathrm{M}$ \\
\hline Margonin & $\mathrm{s}$ & $\mathrm{XV}$ & & & & & 6 & & & 5 & 40 & 3 & M \\
\hline Międzychód & $\mathrm{s}$ & XIV & & & & & 4 & 1,3 & & 3 & 39 & 4 & M \\
\hline Śmigiel & $\mathrm{s}$ & XIV & & & & & 7 & 13,3 & & 29 & 38 & 3 & $\mathrm{M}$ \\
\hline Skwierzyna & $\mathrm{k}$ & XIV & & & & + & 6 & 7,1 & & 16 & 36 & 3 & $\mathrm{M}$ \\
\hline Bnin & $\mathrm{s}$ & XIV & & & & & 3 & 3,4 & & 11 & 36 & 3 & $\mathrm{M}$ \\
\hline Pniewy & $\mathrm{s}$ & XIV & & & & + & 6 & 12,8 & & 18 & 35 & 3 & $\mathrm{M}$ \\
\hline
\end{tabular}




\begin{tabular}{|c|c|c|c|c|c|c|c|c|c|c|c|c|c|}
\hline 1 & 2 & 3 & 4 & 5 & 6 & 7 & 8 & 9 & 10 & 11 & 12 & 13 & 14 \\
\hline Raszków & $\mathrm{s}$ & $\mathrm{XV}$ & & & & & 1 & 0,5 & & 6 & 34 & 4 & $\mathrm{M}$ \\
\hline Ostroróg & $\mathrm{s}$ & $\mathrm{XV}$ & & & & + & 4 & 2,4 & & 4 & 33 & 3 & $\mathrm{M}$ \\
\hline Łekno & d & XIV & & & & + & 10 & 13,2 & & 6 & 30 & 3 & $\mathrm{~S}$ \\
\hline Pobiedziska & $\mathrm{k}$ & XIII & & & & + & 15 & 16,2 & 8 & 19 & 29 & 2 & $\mathrm{~S}$ \\
\hline Złotów & $\mathrm{s}$ & XIV & & & & & & & & 19 & 29 & 4 & $\mathrm{~S}$ \\
\hline Chodzież & $\mathrm{s}$ & $\mathrm{XV}$ & & & & + & 2 & & & 11 & 28 & 3 & $\mathrm{~S}$ \\
\hline Powidz & $\mathrm{k}$ & XIII & & & & & & 2,7 & & 6 & 28 & 4 & $\mathrm{~S}$ \\
\hline Skoki & $\mathrm{s}$ & XIV & & & & & 3 & 3,8 & & 4 & 27 & 4 & $\mathrm{~S}$ \\
\hline Krajenka & $\mathrm{s}$ & $\mathrm{XV}$ & & & & & & & & 15 & 27 & 4 & $\mathrm{~S}$ \\
\hline Mrocza & $\mathrm{s}$ & XIV & & & & & & & & 10 & 27 & 4 & $\mathrm{~S}$ \\
\hline Iwanowice & $\mathrm{s}$ & $\mathrm{XV}$ & & & & & & & & 2 & 26 & 4 & $\mathrm{~S}$ \\
\hline Stanisławowo & $\mathrm{s}$ & XVI & & & & & & & & & 26 & 4 & $\mathrm{~S}$ \\
\hline Kazimierz & $\mathrm{s}$ & XIII & & & & & 6 & 2,5 & & 13 & 25 & 3 & $\mathrm{~S}$ \\
\hline Barcin & $\mathrm{s}$ & XVI & & & & & & & & 2 & 25 & 4 & $\mathrm{~S}$ \\
\hline Mielżyn & $\mathrm{s}$ & XVI & & & & & & & & 4 & 25 & 4 & $\mathrm{~S}$ \\
\hline Miasteczko & $\mathrm{s}$ & $\mathrm{XV}$ & & & & & & & & 3 & 24 & 4 & $\mathrm{~S}$ \\
\hline Książ & $\mathrm{s}$ & XIV & & & & & 6 & 2,4 & & 3 & 23 & 3 & $\mathrm{~S}$ \\
\hline Zagórów & d & $\mathrm{XV}$ & & & & & 3 & 0,7 & & 3 & 23 & 4 & $\mathrm{~S}$ \\
\hline Bledzew & d & XVI & & & & & & & & 8 & 23 & 4 & $\mathrm{~S}$ \\
\hline Chodecz & $\mathrm{s}$ & XIV & & & & & 4 & & & 7 & 21 & 4 & $\mathrm{~S}$ \\
\hline Rynarzewo & $\mathrm{s}$ & XIII & & & & & 2 & & & 4 & 21 & 4 & $\mathrm{~S}$ \\
\hline Wieleń & $\mathrm{s}$ & XIV & & & & & 1 & & & 3 & 21 & 4 & $\mathrm{~S}$ \\
\hline Wysoka & $\mathrm{s}$ & XVI & & & & & & & & 6 & 21 & 4 & $\mathrm{~S}$ \\
\hline Brudzew & $\mathrm{s}$ & $\mathrm{XV}$ & & & & + & 6 & 3,5 & & 4 & 20 & 3 & $\mathrm{~S}$ \\
\hline Babimost & $\mathrm{k}$ & XIV & & & & & 4 & 0,7 & & 3 & 20 & 4 & $\mathrm{~S}$ \\
\hline Jaraczewo & $\mathrm{s}$ & XVI & & & & & & & & 3 & 20 & 4 & $\mathrm{~S}$ \\
\hline Czerniewo & $\mathrm{s}$ & XIV & & & & & 4 & 0,7 & & 6 & 18 & 4 & $\mathrm{~S}$ \\
\hline Golina & $\mathrm{s}$ & XIV & & & & & 3 & & & 5 & 18 & 4 & $\mathrm{~S}$ \\
\hline Kórnik & $\mathrm{s}$ & $\mathrm{XV}$ & & & & + & 2 & 3,9 & & 8 & 18 & 3 & $\mathrm{~S}$ \\
\hline Kiszkowo & $\mathrm{s}$ & XIV & & & & & 4 & 8 & & 6 & 17 & 3 & $\mathrm{~S}$ \\
\hline Stęszew & $\mathrm{s}$ & XIV & & & & + & 4 & & & 10 & 16 & 3 & $\mathrm{~S}$ \\
\hline Ryczywół & $\mathrm{s}$ & $\mathrm{XV}$ & & & & & 2 & & 5 & 4 & 16 & 4 & $\mathrm{~S}$ \\
\hline Sulmierzyce & $\mathrm{k}$ & $\mathrm{XV}$ & & & & & & & & 2 & 16 & 4 & $\mathrm{~S}$ \\
\hline Korab & $\mathrm{s}$ & XVI & & & & & & & & 7 & 16 & 4 & $\mathrm{~S}$ \\
\hline Rogowo & $\mathrm{s}$ & XIV & & & & & & & & & 16 & 4 & $\mathrm{~S}$ \\
\hline Przemęt & d & XIV & & & & & 2 & & & & 15 & 4 & $\mathrm{~S}$ \\
\hline Mosina & $\mathrm{s}$ & XIV & & & & & 4 & & & 10 & 14 & 4 & $\mathrm{~S}$ \\
\hline Kamień & d & XIV & & & & & & & & 5 & 14 & 4 & $\mathrm{~S}$ \\
\hline Kębłowo & $\mathrm{s}$ & XIV & & & & + & 4 & 6,5 & & & 13 & 3 & $\mathrm{~S}$ \\
\hline
\end{tabular}




\begin{tabular}{|c|c|c|c|c|c|c|c|c|c|c|c|c|c|}
\hline 1 & 2 & 3 & 4 & 5 & 6 & 7 & 8 & 9 & 10 & 11 & 12 & 13 & 14 \\
\hline Sarnowa & $\mathrm{s}$ & $\mathrm{XV}$ & & & & & 4 & 0,2 & & 6 & 13 & 4 & $\mathrm{~S}$ \\
\hline Opalenica & $\mathrm{s}$ & $\mathrm{XV}$ & & & & & 1 & & & 4 & 13 & 4 & $\mathrm{~S}$ \\
\hline $\begin{array}{l}\text { Sępólno } \\
\text { Krajeńskie }\end{array}$ & $\mathrm{s}$ & XIV & & & & & 0 & & & 5 & 13 & 4 & $\mathrm{~S}$ \\
\hline Brdów & $\mathrm{s}$ & XVI & & & & & & & & 2 & 13 & 4 & $\mathrm{~S}$ \\
\hline Tuliszków & $\mathrm{s}$ & $\mathrm{XV}$ & & & & & 5 & 9,4 & & 5 & 12 & 3 & $\mathrm{~S}$ \\
\hline Kwieciszewo & $\mathrm{d}$ & XIV & & & & & 2 & 3,8 & & 1 & 12 & 4 & $\mathrm{~S}$ \\
\hline Wójtostwo & $\mathrm{s}$ & $\mathrm{XVI}$ & & & & & & & & & 12 & 4 & $\mathrm{~S}$ \\
\hline Lądek & $\mathrm{d}$ & XIII & & & & & 1 & 0,2 & & 3 & 11 & 4 & $\mathrm{~S}$ \\
\hline Więcbork & $\mathrm{s}$ & $\mathrm{XV}$ & & & & & & & & 6 & 11 & 4 & $\mathrm{~S}$ \\
\hline Pszczew & $\mathrm{d}$ & XIII & & & & & 4 & 1,8 & & 5 & 10 & 4 & $\mathrm{~S}$ \\
\hline Odolanów & $\mathrm{k}$ & XIV & & + & & & 4 & 1,3 & & 2 & 10 & 4 & $\mathrm{~S}$ \\
\hline Ostrów & $\mathrm{d}$ & XIV & & & & & 2 & & & & 10 & 4 & $\mathrm{~S}$ \\
\hline Kopanica & $\mathrm{s}$ & $\mathrm{XV}$ & & & & & 2 & 0,8 & & 3 & 10 & 4 & $\mathrm{~S}$ \\
\hline Grzybowo $^{28}$ & $\mathrm{~d}$ & XVI & & & & & & & & & 10 & 4 & $\mathrm{~S}$ \\
\hline $\begin{array}{l}\text { Targowa } \\
\text { Górka }\end{array}$ & $\mathrm{s}$ & XIV & & & & & 4 & & & & 9 & 4 & $\mathrm{~S}$ \\
\hline Kamionna & $\mathrm{s}$ & XV & & & & & 3 & 1,4 & & 3 & 9 & 4 & $\mathrm{~S}$ \\
\hline Jutrosin & $\mathrm{s}$ & $\mathrm{XV}$ & & & & & & 1,9 & & 12 & 9 & 4 & $\mathrm{~S}$ \\
\hline Łopienno & $\mathrm{s}$ & XVI & & & & & & & & 3 & 9 & 4 & $\mathrm{~S}$ \\
\hline Człopa & $\mathrm{s}$ & XIV & & & & & 4 & & & & 8 & 4 & $\mathrm{~S}$ \\
\hline Kazimierz & $\mathrm{s}$ & XIV & & & & & 3 & 2,5 & & 8 & 8 & 4 & $\mathrm{~S}$ \\
\hline Wielichowo & $\mathrm{d}$ & $\mathrm{XV}$ & & & & & 2 & 0,2 & & 2 & 8 & 4 & $\mathrm{~S}$ \\
\hline Orchowo & $\mathrm{s}$ & XVI & & & & & & 2,7 & & 1 & 8 & 4 & $\mathrm{~S}$ \\
\hline $\begin{array}{l}\text { Sobótka } \\
\text { Wielka }\end{array}$ & $\mathrm{s}$ & $X V$ & & & & & & & & & 8 & 4 & $\mathrm{~S}$ \\
\hline Stobnica & $\mathrm{s}$ & $\mathrm{XV}$ & & & & & & 3,5 & 3 & 3 & 8 & 4 & $\mathrm{~S}$ \\
\hline Ujście & $\mathrm{k}$ & $\mathrm{XV}$ & & & & & 10 & & 10 & 3 & 7 & 3 & $\mathrm{~S}$ \\
\hline Mieścisko & $\mathrm{k}$ & $\mathrm{XV}$ & & & & & 4 & 0,7 & & 11 & 7 & 4 & $\mathrm{~S}$ \\
\hline Janowiec & $\mathrm{s}$ & $\mathrm{XV}$ & & & & & 2 & 4,5 & & 2 & 7 & 4 & $\mathrm{~S}$ \\
\hline Trzciel & $\mathrm{s}$ & XIV & & & & & 2 & 2,2 & & 4 & 7 & 4 & $\mathrm{~S}$ \\
\hline Dubin & $\mathrm{s}$ & $\mathrm{XV}$ & & & & & 1 & 0,3 & & 6 & 7 & 4 & $\mathrm{~S}$ \\
\hline Gąsawa & $\mathrm{s}$ & XIV & & & & & & & & & 7 & 4 & $\mathrm{~S}$ \\
\hline Ostrów & $\mathrm{s}$ & $\mathrm{XV}$ & & & & & & & & 3 & 7 & 4 & $\mathrm{~S}$ \\
\hline Tuczno & $\mathrm{s}$ & XIV & & & & + & & & & 11 & 7 & 3 & $\mathrm{~S}$ \\
\hline Wilczyn & $\mathrm{s}$ & $\mathrm{XV}$ & & & & + & 3 & 2,9 & & 1 & 6 & 4 & $\mathrm{~S}$ \\
\hline Kwiatków & $\mathrm{s}$ & $\mathrm{XV}$ & & & & & 1 & 0,1 & & 2 & 6 & 4 & $\mathrm{~S}$ \\
\hline
\end{tabular}

${ }^{28}$ Obecnie część Gniezna. 


\begin{tabular}{|c|c|c|c|c|c|c|c|c|c|c|c|c|c|}
\hline 1 & 2 & 3 & 4 & 5 & 6 & 7 & 8 & 9 & 10 & 11 & 12 & 13 & 14 \\
\hline Frydland & $\mathrm{s}$ & XIV & & & & & & & & & 6 & 4 & $\mathrm{~S}$ \\
\hline Żerniki & $\mathrm{s}$ & XIII & & & & & 3 & 7,2 & & 1 & 4 & 3 & $\mathrm{~S}$ \\
\hline Ślesin & d & XIV & & & & & 2 & & & & 4 & 4 & $\mathrm{~S}$ \\
\hline Wylatowo & $\mathrm{d}$ & XIV & & & & & 2 & 0,4 & & & 4 & 4 & $\mathrm{~S}$ \\
\hline Zduny & $\mathrm{k}$ & XIII & & & & & 2 & 1,1 & & 12 & 4 & 4 & $\mathrm{~S}$ \\
\hline Szubin & $\mathrm{s}$ & XV & & & & & 2 & & & 4 & 4 & 4 & $\mathrm{~S}$ \\
\hline Licheń & $\mathrm{s}$ & $\mathrm{XV}$ & & & & & 1 & & & 3 & 4 & 4 & $\mathrm{~S}$ \\
\hline Grzymiszew & $\mathrm{s}$ & $\mathrm{XV}$ & & & & & & 1,3 & & 2 & 4 & 4 & $\mathrm{~S}$ \\
\hline Rozdrażew & $\mathrm{s}$ & $\mathrm{XV}$ & & & & & 2 & & & & 3 & 4 & $\mathrm{~S}$ \\
\hline Dobrzyca & $\mathrm{s}$ & $\mathrm{XV}$ & & & & & 1 & 0,7 & & 6 & 3 & 4 & $\mathrm{~S}$ \\
\hline Jędrzejewo 29 & $\mathrm{~s}$ & XVI & & & & & & & & & 3 & 4 & $\mathrm{~S}$ \\
\hline Smogulec & $\mathrm{s}$ & XIV & & & & & & & & 4 & 3 & 4 & $\mathrm{~S}$ \\
\hline Opatówek & d & XIV & & & & & 2 & & & & 2 & 4 & $\mathrm{~S}$ \\
\hline Gołańcz & $\mathrm{s}$ & XIV & & & & & & & & 16 & 2 & 4 & $\mathrm{~S}$ \\
\hline Brójce & $\mathrm{k}$ & $\mathrm{XV}$ & & & & & & & & 3 & 1 & 4 & $\mathrm{~S}$ \\
\hline Kostrzyn & $\mathrm{d}$ & XIII & & & & + & 3 & 22,1 & & & 0 & 3 & $\mathrm{M}$ \\
\hline $\begin{array}{l}\text { Goślina } \\
\text { Kościelna }\end{array}$ & $\mathrm{s}$ & XIV & & & & & 2 & & 10 & & 0 & 4 & $\mathrm{~S}$ \\
\hline Lewice & $\mathrm{s}$ & $\mathrm{XV}$ & & & & & 1 & 1,3 & & 2 & 0 & 4 & $\mathrm{~S}$ \\
\hline Czaplinek & $\mathrm{d}$ & XIV & & & & & & & & & 0 & 4 & $\mathrm{~S}$ \\
\hline Wałcz & $\mathrm{k}$ & XIV & & & & & & & & 11 & 0 & 3 & $\mathrm{M}$ \\
\hline Opatówek & $\mathrm{d}$ & & & & & & 2 & & & & & 4 & \\
\hline Modrze & $\mathrm{k}$ & & & & & & 2 & 0,9 & & & & 4 & \\
\hline Łubowo & $\mathrm{s}$ & & & & & & 2 & 0,7 & & & & 4 & \\
\hline Stępuchowo & $\mathrm{s}$ & & & & & & 2 & 0,8 & & & & 4 & \\
\hline Brodnica & $\mathrm{s}$ & & & & & & 1 & 1,6 & & & & 4 & \\
\hline Bytyń & $\mathrm{s}$ & & & & & & 1 & 0,2 & & & & 4 & \\
\hline Głęboczek & $\mathrm{s}$ & & & & & & 1 & & & & & 4 & \\
\hline Karmin & $\mathrm{s}$ & & & & & & 1 & & & & & 4 & \\
\hline Lutynia & $\mathrm{s}$ & & & & & & 1 & 0,3 & & & & 4 & \\
\hline Mchy & $\mathrm{s}$ & & & & & & 1 & & & & & 4 & \\
\hline Obrzycko & $\mathrm{s}$ & & & & & & 1 & & & & & 4 & \\
\hline Pogorzel & $\mathrm{s}$ & & & & & & 1 & 0,3 & & 5 & & 4 & \\
\hline Potarzyca & $\mathrm{s}$ & & & & & & 1 & & & & & 4 & \\
\hline $\begin{array}{l}\text { Srebrna } \\
\text { Górka }\end{array}$ & $\mathrm{s}$ & & & & & & 1 & & & & & 4 & \\
\hline Czeszewo & $\mathrm{s}$ & & & & & & & & & & & 4 & \\
\hline
\end{tabular}

${ }^{29}$ Obecnie część Gniezna. 


\section{Bibliografia}

Atlas historyczny Polski. Rejestry poborowe województwa kaliskiego w XVI w., red. M. Słoń, „Atlas Źródeł i Materiałów do Dziejów Dawnej Polski” 2, 2015, Atlasfontium.pl.

Atlas historyczny Polski. Rejestry poborowe województwa poznańskiego $w$ XVI $w$., red. M. Słoń, „Atlas Źródeł i Materiałów do Dziejów Dawnej Polski” 3, 2015, Atlasfontium.pl.

Bieniaszewski A., Latzke J., Rejestr poboru cyzy z miast Wielkopolski w latach 1462-1465, PH, t. 68,1977 , s. 541-553.

Bogucka M., Samsonowicz H., Dzieje miast i mieszczaństwa w Polsce przedrozbiorowej, Wrocław 1986.

Kłoczowski J., Klöster und Orden im mittelalterlichen Polen, Osnabrück 2013, s. $236-303$.

Łaski J., Liber beneficiorum archidyecezyi gnieźnieńskiej, t. 1-2, wyd. J. Łukowski, J. Korytkowski, Gniezno 1880-1881.

Nowacki J., Dzieje archidiecezji poznańskiej, t. 2: Archidiecezja poznańska $w$ granicach historycznych i jej ustrój, Poznań 1964, s. 650-665.

Rutkowski H., Podatek „koronacja” w Polsce na poczatku XVI wieku, w: tenże, Fundamenta historiae. Pisma wybrane, oprac. M. Zbieranowski, M. Słoń, Warszawa 2014, s. 53-70.

Stownik historyczno-geograficzny ziem polskich $w$ średniowieczu, red. T. Jurek, www.slownik.ihpan.edu.pl.

Volumina constitutionum, t. 1, vol. 1: 1493-1526, wyd. S. Grodziski, I. Dwornicka, W. Uruszczak, Warszawa 1996, s. 350-362.

Widawski J., Miejskie mury obronne w Państwie Polskim do poczatku XV w., Warszawa 1973.

Wiesiołowski J., Dominikanie w miastach wielkopolskich w okresie średniowiecza, w: Studia nad historia dominikanów w Polsce 1222-1972, t. 1, red. J. Kłoczowski, Warszawa 1975, s. 199-215.

Wiesiołowski J., Sieć miejska w Wielkopolsce XIII-XVI wieku. Przestrzeń $i$ spoteczeństwo, KHKM, t. 28, 1980, nr 3, s. 385-395.

Wyrobisz A., Rola miast prywatnych w Polsce XVI-XVII wieku, PH, t. 65, 1974, s. $19-46$.

Marek Słoń

Private towns in the urban network of Greater Poland in the $15^{\text {th }}-16^{\text {th }}$ century

(Summary)

The aim of the paper is to present the importance of private towns in the urban network of Kaliskie Voivodeship and Poznańskie Voivodeship in the $15^{\text {th }}$ and the $16^{\text {th }}$ century. In the analysis of the situation in the $15^{\text {th }}$ century, the 
urban centres are divided into four categories. Apart from the list of infantrymen raised for the purposes of the 1458 war, which turned out to be the only basis of the list for Greater Poland developed by H. Samsonowicz, the analysis also encompasses such criteria as the collection of excise tax in the years 1463-1464, coronation tax of 1507, rate of municipal tax determined in tax collection registers from the second half of the $16^{\text {th }}$ century, list of towns of the $2^{\text {nd }}$ order from 1520, and the existence of city walls, mendicant convents and hospitals. The analysis of the situation towards the end of the $16^{\text {th }}$ century is based on the calculations of J. Wiesiołowski, expanded by the application of a wider selection of source materials, that is with the use of all tax collection registers from the second half of the century and with a more thorough justification for the methodology selected. The results obtained on the basis of these two methodologies are juxtaposed for their mutual verification and in order to indicate changes in the $16^{\text {th }}$-century urban network. The deliberations are concluded with the analysis of the network and the dynamics of the foundation process through the prism of the classification performed in the paper. Selected data is also presented in the form of graphs and maps. All source data used in the paper is collated in the annex.

Marek Słoń - dr hab., profesor Instytutu Historii PAN, gdzie kieruje Zakładem Atlasu Historycznego. Zainteresowania badawcze: dzieje miasta i jego religijności, edytorstwo źródeł, historia osadnictwa i geografia historyczna, Wielkopolska w XVI w. Opublikował m.in.: Szpitale średniowiecznego Wroctawia, Warszawa 2000; Entrate stabili in un'economia instabile. Le strategie economiche degli ospedali dell'Europa centrale nel Medioevo: l'esempio di Breslavia, w: Le interazioni fra economia e ambiente biologico nell'Europa preindustriale, secc. XIII-XVIII, wyd. S. Cavaciocchi, Firenze 2010, s. 423-436; Miasta podwójne i wielokrotne w średniowiecznej Europie, Wrocław 2011; Fundatio civitatis. Städtische Lokation und kirchliches Stiftungsprogramm in Breslau, Krakau und Posen, w: Rechtsstadtgründungen im mittelalterlichen Polen, wyd. E. Mühle, Köln-Weimar-Wien 2011, s. 107-126; Pryncypia edytorstwa źródet historycznych $w$ dobie rewolucji cyfrowej, „Studia Źródłoznawcze" 53, 2015, s. 155-161. E-mail: marek.slon@wp.pl. 